\title{
The response of inorganic carbon distributions and dynamics to upwelling-favorable winds on the northern Gulf of Mexico during
}

\section{summer}

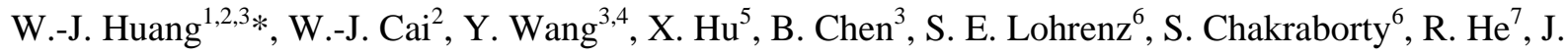
Brandes $^{8}$ and C. S. Hopkinson ${ }^{3}$

[1] \{Department of Oceanography, National Sun Yat-Sen University, Kaohsiung 80424, Taiwan.\}

[2] S School of Marine Science and Policy, University of Delaware, Newark, DE 19716, USA\}

[3] \{Department of Marine Sciences, University of Georgia, Athens, GA 30602, USA

[4] \{Yongchen Wang is deceased and was responsible for equipment and the supervision of field work. \}

[5] \{Department of Physical \& Environmental Sciences, Texas A\&M University-Corpus Christi, Corpus Christi, TX 78412, USA

[6] S School of Marine Science and Technology, University of Massachusetts-Dartmouth, New Bedford, MA 02744 USA

[7] \{Department of Marine, Earth and Atmospheric Sciences, North Carolina State University, Raleigh, NC 27695, USA\}

[8] \{Skidaway Institute of Oceanography, 10 Ocean Science Circle, Savannah, GA 31411, USA\}

*Correspondence to: W.-J. Huang (wjhuang29@mail.nsysu.edu.tw) 


\begin{abstract}
Upwelling-favorable winds and an offshore-distributed Mississippi and Atchafalaya River plume trajectory were observed in summer 2009 in contrast to the mean conditions from 2002 to 2010 (upwelling-unfavorable winds and an alongshore river plume trajectory), a set of conditions which was also observed in summer 2007. The responses of dissolved inorganic carbon (DIC) distributions and dynamics to upwelling-favorable winds are studied by comparing the contrasting conditions between summer 2009 and summer 2007 on the northern Gulf of Mexico. Patterns of surface water partial pressure of $\mathrm{CO}_{2}\left(p \mathrm{CO}_{2}\right)$, DIC, $\delta^{13} \mathrm{C}$ in DIC, and total alkalinity (TA) determined in July 2009 and August 2007 were strongly related to river plume trajectories, and differed between the two summers.
\end{abstract}

The slope of the relationship between dissolved oxygen (DO) and DIC in summer 2007 was comparable to the Redfield $\mathrm{O} / \mathrm{C}$ ratio of 1.3 , which was attributed to respiration of organic matter in the bottom water. The slope of the DO and DIC relationship and $\delta^{13} \mathrm{C}_{\text {DIC }}$ values in bottom waters during July 2009 were clearly affected by mixing since their salinities were $<35$. A three end-member mixing model was used to remove mixing effects in 1) $\delta^{13} \mathrm{C}_{\text {DIC }}$, to estimate the organic source of respiration, and 2) in DIC concentrations, to calculate DIC removal and release. $\delta^{13} C_{\text {DIC }}$ results in both summers were consistent with an apparent release of DIC in hypoxic waters (DO less than $2 \mathrm{mgL}^{-1}$ ) associated with respiration of surface organic matter. The area-weighted surface DIC removal (i.e., biological production) was lower in 2009 than in 2007 on the shelf, as the plume was distributed offshore. The release of DIC in bottom waters was higher over the shelf in 2009 and was surmised to be related to stronger mixing, which was favorable for the DO supply for respiration. Overall, surface waters on the continental shelf in the region of study in July 2009 acted as a weak $\mathrm{CO}_{2}$ source to the atmosphere, but a weak $\mathrm{CO}_{2}$ sink in August 2007. We contend that the inorganic carbon distribution and concentrations on the shelf were related to regional wind forcing, through its influence on the distribution of coastal currents and plume trajectories and their subsequent impact on biogeochemical processes. 


\section{Introduction}

Despite its relatively small global areal coverage, the coastal ocean contributes substantially to the global carbon cycle through net biological production and export of organic carbon to the open ocean (Bauer and Bianchi, 2011) as well as through air-sea carbon dioxide $\left(\mathrm{CO}_{2}\right)$ gas exchange (Cai, 2011; Chen and Borges, 2009; Cai et al., 2006). The coastal ocean faces serious perturbations that can alter the carbon cycle, such as through varying river export of inorganic carbon and rising atmospheric $\mathrm{CO}_{2}$ levels (Bauer et al., 2013; Raymond et al., 2008), typhoon-enhanced primary production (Chen et al., under revision), anomalous weather induced air-sea $\mathrm{CO}_{2}$ variations (Ávila et al., under revision), and long-term ocean acidification (Lui et al., under revision). In particular, sea surface nitrogen enrichment through increasing river nitrate flux (McIsaac et al., 2001) can lead to cultural eutrophication (surface algal blooms) and consequent bottom water hypoxia (dissolved oxygen [DO] $<2 \mathrm{mg} \mathrm{L}^{-1}$ ), especially on large-riverdominated continental shelves (Rabalais et al., 2010; Rabouille et al., 2008). Physically, coastal oceans are characterized by a complex shelf circulation that is driven by variations in freshwater discharge, upwelling along the shelf edge, and local wind forcing (Lentz and Fewings, 2012). Variations in shelf circulation can alter the cross- and along-shelf distribution of river plumes and associated nutrients (Bianchi et al., 2010) and consequently the severity of eutrophication.

Outflow from the Mississippi and Atchafalaya rivers is usually distributed westward along the Louisiana shelf during non-summer months (Cochrane and Kelly, 1986; Ohlmann and Niiler, 2005; Smith and Jacobs, 2005) in response to variable wind forcing primarily out of the north and east (Wang et al., 1998). Biogeochemically this circulation pattern produces an alongshore distribution of $p \mathrm{CO}_{2}$ (partial pressure of $\mathrm{CO}_{2}$ ) on the Louisiana shelf (Lohrenz et al., 2010; Huang et al., 2013). Surface water dissolved inorganic carbon (DIC) also exhibits an alongshore distribution, increasing toward the west (Cai et al., 2003; Guo et al., 2012). During summer months, wind forcing out of the south and west can result in a reversal of shelf circulation leading to a pattern of river plume discharge distributed to the east and cross-shelf (Cochrane and Kelly, 1986; Ohlmann and Niiler, 2005; Smith and Jacobs, 2005; Fichot et 
al., 2014). This general summer pattern of Louisiana shelf circulation is greatly dependent on local wind forcing, however (Cochrane and Kelly, 1986; Ohlmann and Niiler, 2005; Smith and Jacobs, 2005). Upwelling favorable winds on continental shelves without large freshwater discharges can induce deep or bottom water rising toward surface. On this large-rive dominated continental shelf, upwelling favorable wind forcing (northerly wind) has been observed irregularly during summers on the northern Gulf of Mexico with high chlorophyll a concentrations expending from the coast line to the offshore and its surrounding open gulf (Fichot et al., 2014). Specifically in July 2009, continuous upwelling-favorable winds along the Louisiana coast have been characterized with cross-shelf river plume trajectories in July 2009 (Zhang et al., 2012; Xue et al., 2013) and have been suggested to be related to a small areal extent of bottom water hypoxia thereafter (Feng et al., 2014; Turner et al., 2012; Bianchi et al., 2010; Forrest et al., 2011; Evans and Scavia, 2011). In order to evaluate the role of biogeochemistry in shelf circulations and their responses to global anthropogenic changes (Rabalais et al., 2010; Doney et al., 2011), there is a need to comprehensively describe the response of inorganic carbon to the upwelling-favorable wind on this shelf, especially given the limited extent of observations during upwelling-favorable wind forcing.

In this study, we assess the circulation and carbon biogeochemical response of the Louisiana shelf to changes in predominant wind fields. We do this by identifying the average summer (July/August) circulation climatology and then comparing that to biogeochemical observations made during August 2007 and July 2009, which respectively represent upwelling-unfavorable and upwelling-favorable summer conditions. Our approach includes an examination of satellite-derived chlorophyll-a (chl-a) and modeled surface currents for a climatologically average summer using 1) multi-year averages of July and August, 2) a summer with upwelling unfavorable winds (August 2007), and 3) a summer with upwelling favorable winds (July 2009). We then describe the distribution of sea surface salinity, surface water $p \mathrm{CO}_{2}$, DIC, and total alkalinity (TA) in the surface and bottom water in both wind conditions. Finally, we describe and discuss air-sea $\mathrm{CO}_{2}$ flux, the spatial extent of bottom water DIC, $\delta^{13} \mathrm{C}$ in DIC $\left(\delta^{13} \mathrm{C}_{\mathrm{DIC}}\right)$, and the relationship between DIC and DO in the bottom water on the Louisiana shelf. 


\section{Methods}

\subsection{Sampling and external data}

Cruises were conducted August 18-24, 2007 on board OSV Bold, and July 19-29, 2009 on board R/V Cape Hatteras on the Louisiana shelf and its adjacent regions. TA and DIC samples were collected from Niskin bottles in thoroughly flushed $250 \mathrm{ml}$ borosilicate glass bottles and then preserved with 100- $\mu \mathrm{L}$ $\mathrm{HgCl}_{2}$ saturated solution. DIC samples were measured shortly after the cruise by acidifying $0.5 \mathrm{~mL}$ of sample and quantifying the released $\mathrm{CO}_{2}$ with an infrared gas analyzer (LI-COR ${ }^{\circledR}$ 6252). TA samples were measured by Gran titration using $0.1 \mathrm{M} \mathrm{HCl}$ and a semi-automated titrator. Both TA and DIC

measurements had a precision of $0.1 \%$ (Cai et al., 2010; Huang et al., 2012). $\delta^{13} \mathrm{C}_{\text {DIC }}$ samples were collected in $2 \mathrm{~mL}$ vials and stored at $4^{\circ} \mathrm{C}$ until analysis. $\delta^{13} \mathrm{C}_{\mathrm{DIC}}$ was measured using liquid chromatography coupled to an isotope-ratio mass spectrometer with a precision of $0.06 \%$ (Brandes 2009). DO concentrations were measured using the sensor mounted on a vertical conductivity, temperature, and depth (CTD) array. The calibration of DO concentration was verified by comparison to Winkler titration based on samples collected from the Niskin bottle.

For sea surface salinity and $p \mathrm{CO}_{2}$ measurements, seawater was sampled from the ship flowthrough whose inlet was at about one meter depth. $p \mathrm{CO}_{2}$ was measured by a flow-through system with a shower head equilibrator plus a $\mathrm{CO}_{2}$ analyzer (LI-COR 7000) (Jiang et al., 2008; Huang et al., 2015). The LI-COR ${ }^{\circledR} 7000$ was calibrated every 3.5 to $6 \mathrm{hr}$ using four certified gas standards, which had dry $\mathrm{CO}_{2}$ molar fractions of $197.45,400.57,594.65$, and 975.26 ppm referenced against standards traceable to the National Institute of Standards and Technology. Area averaged $p \mathrm{CO}_{2}$ values were gridded to a resolution of $0.1^{\circ} \times 0.1^{\circ}$ and were used to calculate the air-sea $\mathrm{CO}_{2}$ flux using the following equation:

$\mathrm{CO}_{2}$ Flux $=\mathrm{k} \times \mathrm{K}_{0} \times\left(p \mathrm{CO}_{2 \mathrm{sw}}-p \mathrm{CO}_{2 \mathrm{air}}\right)$ 
where k represents the gas transfer velocity; $\mathrm{K}_{0}$ is the solubility of $\mathrm{CO}_{2}$ (Weiss, 1974); and $p \mathrm{CO}_{2} \mathrm{Sw}$ and $p \mathrm{CO}_{2}$ air are the $p \mathrm{CO}_{2}$ in surface seawater and the overlying atmosphere, respectively. We adopt the equation given by Ho et al., (2006) to calculate the air-sea gas transfer coefficient. More details about the calculation of air-sea $\mathrm{CO}_{2}$ flux were described by Huang et al. (2015). Spatial wind forcing data were from QuikSCAT (Quick Scatterometer from NOAA's Ocean Watch Live Access Server, http://las.pfeg.noaa.gov/ocean-Watch/oceanwatch.php) ocean surface winds data with a resolution of $0.25^{\circ}$. The wind forcing time series record was from the LUML1 station at Louisiana coast $\left(29.255^{\circ} \mathrm{N}\right.$, $\left.90.663^{\circ} \mathrm{W}\right)$ and the buoy (NOAA station \#42043) near Galveston Texas $\left(28.982^{\circ} \mathrm{N}, 94.898^{\circ} \mathrm{W}\right)$. Eightday composites of MODIS-Aqua chl- $a$ data from 2002 to 2010 were acquired from NASA's (The National Aeronautics and Space Administration's) Ocean Color Web (http://oceancolor.gsfc.nasa.gov/) and were used to illustrate the synoptic trajectory of the river plume (Del Castillo et al., 2001; Jones and Wiggert, 2015; Nababan et al., 2011). Hu et al. (2003) have compared satellite-derived and in situ measurements on the northern Gulf of Mexico and have reported a percentage error less than 50\% between them. We applied the Hybrid Coordinate Ocean Model (HYCOM, Naval Research Laboratory, http://hycom.org/, HYCOM + NCODA Gulf of Mexico 1/25 Analysis)derived sea surface currents to illustrate general shelf circulation from 2003 to 2010. The slope of the DOto-DIC relationship was determined by Type II regression (York, 1966) considering uncertainties in both DO and DIC analyses.

\subsection{Three end-member mixing model}

We follow Huang et al. (2012) and assume DIC and nutrient concentrations were dominated by mixing and biological activity. Conservatively, one unit of water is the sum of the fraction (f) from each endmember: the Mississippi River (subscripted M), the Atchafalaya River (subscripted A), and seawater (subscripted S) as follows:

$$
\begin{aligned}
& 1=f_{M}+f_{A}+f_{S} \\
& \text { Sal }=\text { Sal }_{M} \times f_{M}+\operatorname{Sal}_{A} \times f_{A}+\operatorname{Sal}_{S} \times f_{S}
\end{aligned}
$$


where Sal is our measured salinity, Sal with abbreviations is the salinity of each end-member, respectively. Measured TA and $\mathrm{NO}_{3}$ are further affected by biological uptake.

$$
\begin{aligned}
& \mathrm{TA}=\mathrm{TA}_{\mathrm{M}} \times \mathrm{f}_{\mathrm{M}}+\mathrm{TA}_{\mathrm{A}} \times \mathrm{f}_{\mathrm{A}}+\mathrm{TA}_{\mathrm{S}} \times \mathrm{f}_{\mathrm{S}}+\mathrm{NO}_{3 \text { Bio }} \ldots \ldots . . . \\
& \mathrm{NO}_{3}=\mathrm{NO}_{3 \mathrm{M}} \times \mathrm{f}_{\mathrm{M}}+\mathrm{NO}_{3 \mathrm{~A}} \times \mathrm{f}_{\mathrm{A}}+\mathrm{NO}_{3 \mathrm{~S}} \times \mathrm{f}_{\mathrm{S}}-\mathrm{NO}_{3 \text { Bio }}
\end{aligned}
$$

where subscripted "Bio" represents the biological uptake of the parameter. In order to combine equations (4) and (5), equation (5) can be reorganized as follows:

$$
\mathrm{NO}_{3 \text { Bio }}=\mathrm{NO}_{3 \mathrm{M}} \times \mathrm{f}_{\mathrm{M}}+\mathrm{NO}_{3 \mathrm{~A}} \times \mathrm{f}_{\mathrm{A}}+\mathrm{NO}_{3 \mathrm{~S}} \times \mathrm{f}_{\mathrm{S}}-\mathrm{NO}_{3}
$$

Thus, $\mathrm{NO}_{3 \mathrm{Bio}}$ in equation (4) can be replaced by equation (6). Equation (4) is further reorganized as follows:

$$
\mathrm{TA}+\mathrm{NO}_{3}=\left(\mathrm{TA}+\mathrm{NO}_{3}\right)_{\mathrm{M}} \times \mathrm{f}_{\mathrm{M}}+\left(\mathrm{TA}+\mathrm{NO}_{3}\right)_{\mathrm{A}} \times \mathrm{f}_{\mathrm{A}}+\left(\mathrm{TA}+\mathrm{NO}_{3}\right)_{\mathrm{S}} \times \mathrm{f}_{\mathrm{S}}
$$

As TA and $\mathrm{NO}_{3}$ are measurements, the fractions from each endmember were solved along with the endmembers of salinity, TA, DIC, and $\mathrm{NO}_{3}$ (Table A) using equations (2), (3), and (7) with a non-negative solver (NNLS in Matlab ${ }^{\circledR}$ ). Furthermore, we define the difference between DIC and the conservative mixing DIC value as biological removal or release $(\Delta \mathrm{DIC})$ :

$$
\Delta \mathrm{DIC}=\mathrm{DIC}_{\mathrm{M}} \times \mathrm{f}_{\mathrm{M}}+\mathrm{DIC}_{\mathrm{A}} \times \mathrm{f}_{\mathrm{A}}+\mathrm{DIC}_{\mathrm{S}} \times \mathrm{f}_{\mathrm{S}}-\mathrm{DIC}
$$

We assume the formation of $\delta^{13} \mathrm{C}_{\text {DIC }}$ in bottom hypoxic waters is the product of respiration and mixing of river and sea end-members.

$\delta^{13} \mathrm{C} \times \mathrm{DIC}=\delta^{13} \mathrm{C}_{\mathrm{M}} \times \mathrm{DIC}_{\mathrm{M}} \times \mathrm{f}_{\mathrm{M}}+\delta^{13} \mathrm{C}_{\mathrm{A}} \times \mathrm{DIC}_{\mathrm{A}} \times \mathrm{f}_{\mathrm{A}}+\delta^{13} \mathrm{C}_{\text {sea }} \times \mathrm{DIC}_{\text {sea }} \times \mathrm{f}_{\text {sea }}+\delta^{13} \mathrm{C}_{\text {resp }} \times \Delta \mathrm{DIC}$

where $\delta^{13} \mathrm{C}_{\text {resp }}$ is assumed to be the $\delta^{13} \mathrm{C}$ values of organic matter source for respiration.

\section{Results}

\subsection{Wind forcing}

The average spatial distribution of wind forcing was weak and southerly or southeasterly over the northern Gulf of Mexico during July and August as demonstrated by the eight-year climatology (Fig. 1a). 
These average conditions were similar to those observed during our August 2007 cruise (Fig. 1b). During our July 2009 cruise, however, the wind pattern was quite different, coming from the south along the Texas coast and the southwest over the Louisiana coast. The wind forcing was upwelling-favorable for the Louisiana shelf (Fig. 1c). Based on data from buoy and land stations the average wind direction and speed in July and August over the interval 2004 to 2011 was southerly (182 \pm 94.7 degrees and $3.2 \pm 1.8$ $\mathrm{m} \mathrm{s}^{-1}$ at buoy LUML1, Louisiana and $175 \pm 61.7$ degrees and $4.6 \pm 2.1 \mathrm{~m} \mathrm{~s}^{-1}$ at Galveston, TX). Wind forcing in August 2007 was similar: $169.4 \pm 94.6$ degrees and $3.1 \pm 1.4 \mathrm{~ms}^{-1}$ at LUML1, Louisiana and $172.2 \pm 82.1$ degrees and $4.0 \pm 2.1 \mathrm{~ms}^{-1}$ at Galveston, TX) (F-test, P > 0.05). In July 2009 however, the average wind direction and speed were significantly different from the average: $221.6 \pm 55.3$ degrees and $3.4 \pm 1.7 \mathrm{~ms}^{-1}$ at station LUML1 (F-test, $\mathrm{P}<0.05$ ). In Galveston TX it was not different: $189.8 \pm 46.8$ degrees and $5.0 \pm 1.8 \mathrm{~m} \mathrm{~s}^{-1}$ (F-test, $\left.\mathrm{P}>0.05\right)$.

\subsection{Distributions of plume trajectories}

The nine-year average (2002 to 2010) distribution of MODIS-Aqua chl- $a$ concentration in the months of July and August illustrates the average trajectory of the Mississippi and Atchafalaya River outflow (Fig. 2a). High chl- $a$ concentrations were evident around the Mississippi River delta and westward along the Louisiana shelf towards Texas. The HYCOM-simulated eight-year average (2003-2010) surface shelf circulation is similar to that implied by the distribution of chl- $a$ with weak currents in the inner shelf and strong horizontal currents near the boundaries between offshore and open Gulf of Mexico waters between 89 to $95^{\circ} \mathrm{W}$ (Fig. 2a). Only a few scattered high chl- $a$ patches extend offshore to the south in this nineyear average distribution. The chl-a distribution observed in August 2007 was similar to the long-term trend, thus confirming that this cruise was conducted during upwelling-unfavorable summer conditions. (Fig. 2b). In this upwelling-unfavorable summer, salinities less than 33 were observed immediately adjacent to the Southwest pass of the Mississippi River and along the inner Louisiana shelf towards Texas (Fig. 3a). The distributions of chl- $a$ and salinity displayed an alongshore plume trajectory in August 2007. Looking seaward (Box A in Fig. 2), we observed high chl- $a$ concentrations on the inner and middle 
shelves and low chl- $a$ concentrations on the outer shelf and open gulf for both the nine-year average and August 2007 time frames (Fig. 4). Furthermore, the cross-shelf component of surface currents in the same region (Box A) was similar between the eight-year average $\left(0.02 \mathrm{~ms}^{-1}\right)$ and the value in August 2007 $\left(0.01 \mathrm{~ms}^{-1}\right)$.

Plume distributions as illustrated by chl-a were quite different in July 2009, being high in the inner shelf and out to the open Gulf east of $91.5^{\circ} \mathrm{W}$ (Fig. 2c), especially immediately south of the river delta (Fig. 4). Inner shelf currents were particularly strong toward Louisiana (Fig. 2c) resulting in salinities being above 35 at stations on the inner shelf to the west of $93^{\circ} \mathrm{W}$ (Fig. 3b). Lower salinity waters (salinity less than 33) were confined mostly to the east of $91.5^{\circ} \mathrm{W}$, except for a small pocket immediately next to the Atchafalaya River and Bay (Fig. 3b), and they extended to the open Gulf to the east of $91.5^{\circ} \mathrm{W}$. Cross-shelf currents were observed along $28^{\circ} \mathrm{N}$ between $89^{\circ} \mathrm{W}$ to $94^{\circ} \mathrm{W}$ during our July 2009 sampling (Fig. 2c). The offshore component in the region of Box A was $0.09 \mathrm{~ms}^{-1}$, which was faster than the 8-year average $\left(0.02 \mathrm{~ms}^{-1}\right)$ and August $2007\left(0.01 \mathrm{~ms}^{-1}\right)$. Overall, the combination of chl- $a$ and salinity distributions demonstrated an offshore transport of the river plume to the east of $91.5^{\circ} \mathrm{W}$ during our July 2009 sampling period. High salinity seawater on the inner shelf west of $92.5^{\circ} \mathrm{W}$ was observed, and its source was evident from $\delta^{13} \mathrm{C}_{\mathrm{DIC}}$, which is discussed in the following paragraphs.

\subsection{Distribution of TA, $p \mathrm{CO}_{2}$, DIC, and $\delta^{13} \mathrm{C}_{\mathrm{DIC}}$}

Sea surface spatial distributions of TA, DIC, and $\delta^{13} \mathrm{C}_{\text {DIC }}$ were different between August 2007 and July 2009. In August 2007, low TA and DIC, values were observed on the inner shelf west of $93.5^{\circ} \mathrm{W}$ (Fig. 5). But at the same area, high TA, $p \mathrm{CO}_{2}$, DIC, and $\delta^{13} \mathrm{C}_{\mathrm{DIC}}$ values were observed on the inner in July 2009 (Fig. 5). We also observed low TA, $p \mathrm{CO}_{2}$, DIC, and $\delta^{13} \mathrm{C}_{\mathrm{DIC}}$ values that extended from the inner to outer shelves east of $91^{\circ} \mathrm{W}$ in July 2009 (Fig. 5). These high values west of $93^{\circ} \mathrm{W}$ in July 2009 were generally observed in August 2007. The isotope data, $\delta^{13} \mathrm{C}_{\text {DIC }}$, was consistent with satellite and modelled currents in July 2009, i.e. $\delta^{13} \mathrm{C}_{\text {DIC }}$ values were close to $0 \%$ (open ocean signal) on the inner shelf to the west of $93^{\circ} \mathrm{W}$ and were $-2 \%$ (biological uptake signal) at the offshore along $90.4^{\circ} \mathrm{W}$. 
There were similar gradients in TA and DIC in bottom waters that differed between 2007 and 2009. TA increased in an offshore direction while DIC was low on both inner and outer shelves and highest on the middle shelf in August 2007 (Fig. 6). For July 2009, we only focused on the bottom waters north of $28.2^{\circ} \mathrm{N}$. TA and DIC still showed stable values to the west of $93^{\circ} \mathrm{W}$ but a cross-shelf gradient was observed to the east of $92^{\circ} \mathrm{W}$ in the bottom water (Fig. 6). Although we only have limited $\delta^{13} \mathrm{C}_{\text {DIC }}$ data in bottom water, it showed a pattern similar to the above features: lower $\delta^{13} C_{\text {DIC }}$ values $(<-1 \%$ in bottom waters along $91^{\circ} \mathrm{W}$ toward offshore. Such low values were only observed on the inner shelf in August 2007 (Fig. 6c,f).

\subsection{Distributions of air-sea $\mathrm{CO}_{2}$ flux, surface DIC removal and bottom DIC release}

In comparing air-sea $\mathrm{CO}_{2}$ fluxes between the two conditions, we confined our analysis to the smaller survey area of the August 2007 cruise (generally within the 100-m isobath). Results show that the shelf acted as a weak $\mathrm{CO}_{2}$ sink to the atmosphere $\left(-2.0 \pm 0.20 \mathrm{mmol} \mathrm{m}^{-2} \mathrm{~d}^{-1}\right)$ in August 2007, but a weak source $\left(1.4 \pm 0.13 \mathrm{mmol} \mathrm{m}^{-2} \mathrm{~d}^{-1}\right)$ in July 2009 (Table 1). This difference in behavior was mainly due to the difference in seawater $p \mathrm{CO}_{2}$ levels in the western area between the two years (Fig. 5). The $\Delta \mathrm{CO}_{2}$ flux was $4.96 \mathrm{mmol} \mathrm{m}^{-2} \mathrm{~d}^{-1}$ on the western area in contrast to $2.7 \mathrm{mmol} \mathrm{m}^{-2} \mathrm{~d}^{-1}$ on the eastern area.

In the surface waters, biological DIC removal was high (e.g., net biological production of organic carbon) on the inner shelf and low on the outer shelf in August 2007 (Fig. 7a). In July 2009, surface DIC removal was observed to the east of $91.5^{\circ} \mathrm{W}$ (generally 38 to 70 ) (Fig. 7b), but surface DIC release was also observed to the west of $93^{\circ} \mathrm{W}$ ( $\Delta \mathrm{DIC}=-7$ to $-15 \mu \mathrm{M}$ with the lowest value of $-77 \mu \mathrm{M}$ at inner shelf along $93.4^{\circ} \mathrm{W}$ ) (Fig. 7b). Overall, the integrated surface DIC removal on the shelf in July 2009 was 81.8 $\mu \mathrm{M}$ less than in August 2007 (Table 1). This result was consistent with observations that high productivity was transported off-shore and low productivity waters were observed on the shelf to the west of $92.5^{\circ} \mathrm{W}$ in July 2009.

In the bottom water, DIC release (net biological respiration of organic carbon) demonstrated a cross-shelf gradient in August 2007, i.e., the released DIC concentration was low on the inner and outer 
shelves $(<200 \mu \mathrm{M})$ and was high on the middle shelf $(>200 \mu \mathrm{M})$ (Fig. 7c). Only a small patch of DIC removal was observed in the shallow inner shelf to the west of $93^{\circ} \mathrm{W}$ in August 2007. In July 2009, bottom-water-released DIC was generally observed over this shelf. Released DIC concentration was particularly high at a few stations on the middle to offshore to the east of $92^{\circ} \mathrm{W}$ (Fig. $7 \mathrm{~d}$ ). The integrated result showed that released DIC concentration was 68.3 $\mu \mathrm{M}$ more in July 2009 than in August 2007 (Table 1).

\subsection{DO - DIC Relationships and $\delta^{13} C_{\text {DIC }}$ - salinity relationships}

We observed negative linear relationships between DO and DIC in Louisiana shelf waters, which differed for brackish and high salinity waters and between upwelling-unfavorable and upwelling-favorable summer conditions (Fig 8a). To better illustrate the DO-to-DIC relationships, we separately compared brackish and high salinity waters. We define inner "brackish waters" as inner shelf water with salinity < 35, water depth $<20 \mathrm{~m}$, DO $<150 \mu \mathrm{M}$, and DIC $<2200 \mu \mathrm{M}$. The biogeochemical composition is highly influenced by the river end-member (low salinity, shallow depth, and high DO). Brackish waters along the 10 and $20 \mathrm{~m}$ isobaths parallel the trajectory of plume water in an upwelling-unfavorable year. Bottom waters offshore of the $20 \mathrm{~m}$ isobath showed little salinity variation $(<0.4)$ and were similar in composition to the open ocean end-member (high salinity, deeper depth and high DO). We define "high salinity waters” as more offshore water with salinity $>35$, depth $>20 \mathrm{~m}$ and DO $<150 \mu \mathrm{M}$. In all cases DO and DIC demonstrated negative linear relations: for brackish water, the slope was $-1.0 \pm 0.2\left(\mathrm{R}^{2}=\right.$ $0.826)$; and for high salinity waters, the slope was $-1.2 \pm 0.1\left(\mathrm{R}^{2}=0.836\right)$. Under upwelling-favorable conditions of July 2009, hypoxic conditions were less observed (Fig. 8b) and the slope of the DO-DIC relationship was more negative with brackish and high salinity groupings.

The variation of $\delta^{13} \mathrm{C}_{\text {DIC }}$ was indicative of an influence of mixing (river and seawater) as well as metabolism (Fig. 6, 9). $\delta^{13} \mathrm{C}_{\text {DIC }}$ values were generally higher in surface than in bottom waters, reflecting the net effect of biological production and the net effect of respiration, respectively (Fig. 9). As salinities were lower in hypoxic waters in July 2009 than August 2007, $\delta^{13} \mathrm{C}_{\mathrm{DIC}}$ values were also lower in these 
hypoxic waters in July 2009 (Fig. 9). This mixing effect on $\delta^{13} \mathrm{C}_{\text {DIC }}$ was removed by the mixing model and the result is discussed in 4.3 .

\section{Discussion}

\subsection{The biogeochemical response of surface waters to upwelling-favorable winds}

The characteristics of spatial patterns in surface $p \mathrm{CO}_{2}$, DIC, TA, and chl- $a$ were generally consistent with the characteristics of river discharge trajectories represented by satellite chl- $a$ distributions, i.e. alongshore distribution in August 2007 and offshore transport in July 2009. The distribution of $\mathrm{CO}_{2}$ undersaturated waters (relative to the atmospheric value) as reported in previous studies conducted in summer (Lohrenz et al., 2010; Lohrenz and Cai, 2006, Guo et al., 2012) is generally alongshore, as was the distribution of DIC removal in August 2007. However, in July 2009, the region of $\mathrm{CO}_{2}$ undersaturation and strong DIC removal was restricted to the east of $91.5^{\circ} \mathrm{W}$, which reflected the location of the river plume under the influence of upwelling-favorable winds at that time. As a consequence of this different pattern of $\mathrm{CO}_{2}$ drawdown and DIC removal, the shelf was a weak source in 2009 in contrast to being a sink of atmospheric $\mathrm{CO}_{2}$ in 2007 (Table 1). This biological carbon uptake was also evident from pigment concentrations measured in the same cruise on the open gulf during July 2009: higher chl- $a$ concentrations in the region were affected by the plume in July 2009, compared to upwelling-unfavorable conditions (0.39 $\pm 0.181 \mu \mathrm{g} \mathrm{L}{ }^{-1}$ vs. $0.146 \pm 0.08 \mu \mathrm{g} \mathrm{L}^{-1}$, respectively) (Chakraborty and Lohrenz 2015). On the other hand, the region to the west of $91.5^{\circ} \mathrm{W}$ became negative in $\triangle \mathrm{DIC}$ (releasing DIC) and a strong $\mathrm{CO}_{2}$ source in July 2009. Chen et al. (2000) identified shelf circulation as a factor influencing the distribution of primary production. Similarly, Huang et al. (2013) highlighted wind forcing and strength of river inputs as having a major role in the resultant distributions of surface $p \mathrm{CO}_{2}$ and the air-sea $\mathrm{CO}_{2}$ fluxes in this region. Our results in surface waters were consistent with these previous studies, providing evidence that the distributions of surface salinity, chl- $a, p \mathrm{CO}_{2}$, TA, DIC, and DIC removal can be affected 
by different patterns in wind forcing and shelf circulation through altering the distribution of the plume and its associated enhanced primary production.

Previous study has demonstrated that DIC removal was proportional to nitrate removal and followed the Redfield ratio in this study area (Huang et al., 2012), supporting the view that that this DIC removal was mostly caused by biological production (Cai et al., 2003; Guo et al., 2012). DIC and nitrate removals were high in the middle-to-high salinities in this study and were consistent with prior studies (Guo et al., 2012; Huang et al., 2012). The DIC removal was also accompanied by high chl-a levels in low to middle salinity waters (Chakraborty and Lohrenz 2015). Changes in $\delta^{13} \mathrm{C}_{\mathrm{DIC}}$ might be related to processes such as riverine input of inorganic and organic materials along with mixing, production, respiration, and air-sea gas exchange. We attribute the $\delta^{13} \mathrm{C}_{\text {DIC }}$ values that are higher than the general conservative mixing relationship between river and sea end-members as having likely been elevated by net photosynthesis, while those below this mixing line were likely reduced by net respiration (Fig. 9). Changes in $\delta^{13} \mathrm{C}_{\mathrm{DIC}}$ in hypoxic waters will be further discussed in the next two sections.

\subsection{Bottom water respiration in August 2007}

The relationship between DO and DIC suggested that the variations of DO and DIC concentrations in the bottom water were dominated by microbial respiration. In August 2007, the slope of the DO and DIC regression was $1.0 \pm 0.2\left(\mathrm{R}^{2}=0.826\right)$ in brackish water, and $1.2 \pm 0.1\left(\mathrm{R}^{2}=0.836\right)$ for high salinity waters. Both slopes are similar to Redfield stoichiometry, i.e., the O/C molar ratio is 1.30 (138/106, Redfield, 1958). Such Redfield-type respiration has been observed in hypoxic coastal waters as well (Cantoni et al., 2012; Maske et al., 2010; Hu et al., In press). In addition, we observed that strong surface DIC removal was on the inner shelf (in both surface and shallow bottom waters) while strong bottom DIC removal was on the middle shelf (Fig. 7a,d), suggesting that particulate organic carbon moved from inner shelf to outer shelf and was consistent with a previous study (Fry et al., 2014).

Those values of $\delta^{13} \mathrm{C}_{\text {DIC }}$ below the river-to-sea mixing lines (Fig. 9) were mostly associated with middle and bottom waters and were believed to be related to depletion of $\delta^{13} \mathrm{C}_{\mathrm{DIC}}$ due to respiration activity. Based on our three end-member model, $\delta^{13} \mathrm{C}_{\text {resp }}$ displayed an average of $-21.3 \pm 2.5 \%$ in hypoxic waters in August 2007 (Table 3). This result was consistent with results in previous studies, which ranged 
from -22 \%o to $-22.7 \pm 10.3 \%$ (Strauss et al., 2012; Hu et al., In press), and also in the range of $\delta^{13} \mathrm{C}$ values of -22.5 to $-21.2 \%$ for surface sediment on the inner shelf (Bianchi et al., 2002). For the two outliers in shallow waters (-47.4\%o, $-57.4 \%$ at $10 \mathrm{~m}$ bottom depth), these two $\delta^{13} \mathrm{C}_{\text {DIC }}$ values were probably affected by factors in addition to our assumption (mixing and respiration), such as methane from the marsh and air-sea gas exchange. . Lower $\delta^{13} \mathrm{C}_{\text {resp }}$ values in 10 -m depth compared to values in $>10-\mathrm{m}$ depth were also observed by Strauss et al. (2012) in hypoxic waters. In addition, the three end-member model generated results comparable to the salinity normalized method used by Hu et al., (In press) as the water salinity was above 35 in August 2007 and the effect of variations of river end-members on high salinity waters can be neglected. Assuming $1 \%$ difference in $\delta^{13} \mathrm{C}$ in river end-member DIC variations, the variation is less than $0.002 \%$ when salinity was higher than 35 and was smaller than the resolution of measurements ( $\pm 0.1 \%$ ). The river end-members of $\delta^{13} \mathrm{C}_{\mathrm{DIC}}$ in the Mississippi River (-10.7 \%o at salinity 1.36) and the Atchafalaya River (-9.7 \%o at salinity 0.35 ) were close to the value of -10 \%o reported by Dubois et al., (2010) for the lower Mississippi River waters. The $\delta^{13} \mathrm{C}_{\mathrm{DIC}}$ sea end-member was $0.65 \%$ in August 2007 and was between the two end-members used by Strauss et al. (2012) and Hu et al. (In press), i.e. $0.5 \%$ and $0.8 \%$, respectively (Table 2). In addition, carbonate precipitation and dissolution can also affect $\delta^{13} \mathrm{C}_{\text {DIC }}$. However, this effect can be limited as the fractionation factor of carbonate precipitation is relatively small ( $<3 \%$; Romanek et al., 1992) and the contribution of coccolithphores to variations in DIC is believed to be small (Cai, unpublished data, Guo et al., 2012).

\subsection{The impact of shifting surface biological production on bottom-water DIC release in July 2009}

The area-integrated bottom water-released DIC concentration was $68.3 \mu \mathrm{M}$ higher on the shelf in July 2009 than in August 2007 (Table 1). Please notice that the standard deviations of the area-integrated concentration ( \pm 88.2 and $\pm 69.2 \mu \mathrm{M}$ ) imply spatial variations in August 2007 and July 2009 and they should not be neglected. To reduce these spatial variation, we discuss DIC release in sub-regions. The carbon processing in bottom waters was observed to be similar in the overlapping plume distributions from July 2009 and August 2007 (that is, on the shelf to the east of $92.5^{\circ} \mathrm{W}$ ) and was suggested to be 
different in other three regions as a consequence of the relocated plume. These include 1) the shallow (10 m depth) waters, 2) the inner shelf to the west of $92.5^{\circ} \mathrm{W}$, and 3) the open Gulf to the east of $92.5^{\circ} \mathrm{W}$. On the shelf to the east of $92.5^{\circ} \mathrm{W}$ in July 2009, strong released DIC concentrations in hypoxic waters were observed at two stations along $91^{\circ} \mathrm{W}$ (Fig. 7d). Mixing apparently affected these hypoxic waters as their salinities (34 to 36) were lower than those of hypoxic waters in August 2007 (Fig. 8). The three endmember model was applied again to remove the mixing effect and to estimate the organic matter respired in hypoxic waters in July 2009. The $\delta^{13} \mathrm{C}_{\text {resp }}$ results ranged from $-23.5 \%$ and $-22.1 \%$ at bottom depths of 21.6 and 17.3 m respectively, similar to previous results from August 2007. In contrast, the $\delta^{13} \mathrm{C}_{\text {resp }}$ in shallow waters (bottom depth of $10 \mathrm{~m}$ ) was $-29.4 \%$ and was more ${ }^{13} \mathrm{C}$ enriched than the $\delta^{13} \mathrm{C}_{\text {resp }}$ values at the same depth in August 2007 (-47.4 and -57.4 \%). As this offshore transport event in July 2009 was ephemeral (Feng et al., 2014), the effect of air-sea gas exchange on $\delta^{13} \mathrm{C}_{\text {DIC }}$ was expected to be less than in August 2007 when the water residence time was longer. Thus, this $\delta^{13} C_{\text {resp }}$ value for 10 -m bottom depth in July 2009 might reflect a signal close to the $\delta^{13} \mathrm{C}$ values of soil and plant material in freshwater and salt marshes in Louisiana (-26.5 to $-27.9 \%$ \%) (DeLaune 1986). A better understanding of the underlying mechanisms for the observed $\delta^{13} \mathrm{C}_{\text {resp }}$ results will require further observation as this system was highly dynamic and our estimation was based simply on mixing and respiration. Furthermore, the bottom DIC release was largely reduced on the shelf to the west of $92.5^{\circ} \mathrm{W}$ in July 2009 but the overlying surface $\Delta$ DIC was negative (release of $\mathrm{CO}_{2}$ ). This DIC release might be related to benthic respiration which has already been suggested to be important in this far-field plume during upwelling-unfavorable conditions (Hetland and DiMarco, 2008). On the third region (the surface open gulf to the east of $92.5^{\circ} \mathrm{W}$ ), strong biological uptake characterized by strong DIC removal, $\delta^{13} \mathrm{C}_{\text {DIC }}$ of $-2 \%$, and high chl- $a$ concentrations was observed, implying that the biological pump on this region was enhanced during this rare event in July 2009. Finally,

\subsection{Complex mechanisms behind this highly dynamic system in July 2009}


The surface shelf circulation on the northern Gulf of Mexico, while highly dynamic and complex in summer, was particularly unusual in summer 2009. Coastal current reversal during summer months has been associated with freshwater discharge offshore and to the east of the Mississippi delta (Cho et al., 1998; Wiseman et al., 1997; Nowlin et al., 2005), a pattern consistent with our observations (Fig. 3). Lentz and Fewings (2012) have theoretically described the response of shelf circulation to wind direction for an ideal coastline and topography. Cho et al. (2005) used drifters to reconstruct the shelf circulation in this study area from fall to winter and have modeled the shelf circulation by applying different wind forcing (northeasterly and southwesterly). Their findings attributed the reverse of the Texas-Louisiana shelf current from westward to eastward to the shelf-wide southwesterly wind forcing. Feng et al. (2014) used a 3D model to simulate the reduced hypoxic area in July 2009 and noted the importance of the time period when upwelling wind occurs as a factor influencing the strength of current reversals. The persistent upwelling-favorable wind altered the vertical and horizontal distribution of low salinity waters (Feng et al., 2014). Apparently, riverine nutrients followed the plume trajectory and were removed proportionally to DIC uptake. In addition, light and stratification are non-negligible controlling factors as they have been identified to be important in biological activity and phytoplankton community variability (Lohrenz et al., 1999; Lehrter et al., 2009).

River discharge also played a non-negligible role in addition to the upwelling-favorable wind. The Mississippi and Atchafalaya river discharges were increasing prior to our sampling period in July 2009, while they remained low before the August 2007 sampling effort. Huang et al. (2013) and Fichot et al. (2014) speculated that cross-shelf transport was not only related to upwelling-favorable wind but also to high river discharge in this study area. This is likely, as river discharge has been shown to be correlated with the areal coverage of the river plume and the concentration of total suspended material (Shi and Wang, 2009). In addition, a severe drought occurred in Texas during summer 2009 (NOAA, National Climatic Data Center report). These conditions would have led to low export of freshwater discharge to the shelf and less river-to-sea mixing along the coastline. High salinity water, thus, had a greater 
probability of intruding onto the inner Louisiana shelf to the west of $93^{\circ} \mathrm{W}$ inner shelf, as the $\delta^{13} \mathrm{DIC}$ values on the inner shelf were close to the values in high salinities offshore waters (Fig. 3b).

Gulf-wide wind forcing has been suggested to affect the Loop Current and the coastal currents along Texas and Louisiana shelves (Chang and Oey 2010), as the 10-day surface current exhibits coherence with the establishment of a high pressure atmospheric pressure system over the Gulf of Mexico (Barron and Vastano 1994; Vastano et al., 1995). In a conceptual model provided by Rabalais et al. (2010), the biogeochemical processes were postulated to directly respond not only to local wind forcing, but also to regional weather variation. We suggest that wind conditions dominated the distribution of surface primary production, which subsequently influenced the biogeochemistry of subsurface waters. An atmosphere-terrestrial-ocean biogeochemical model or a large data analysis among these three datasets is needed to fully explain the biogeochemical response on the shelf to regional weather variations.

\section{Summary}

Under an upwelling-unfavorable summer condition as in August 2007, surface distributions of chl- $a$, $p \mathrm{CO}_{2}$, DIC, and TA values were observed to track the Mississippi and Atchafalaya River plume trajectory, which was alongshore and confined to the shelf. Conditions in July 2009, however, differed in that the river plume, along with elevated surface distributions of chl- $a, p \mathrm{CO}_{2}$, DIC, and TA values, were distributed to the east of $91.5^{\circ} \mathrm{W}$ and extended to the Gulf. Similarly, $\delta^{13} \mathrm{C}_{\mathrm{DIC}}$ signals normally characteristic of inner shelf waters were observed in waters of the middle to outer shelf, consistent with the offshore plume trajectory in July 2009. High-productivity plume waters were offshore and lowproductivity seawater was on the western shelf in July 2009, resulting in less surface DIC removal on the shelf under this upwelling-favorable wind event than the mean conditions. Higher area-integrated bottom DIC concentrations on the shelf under this upwelling-favorable wind event compared to the mean conditions might be related to mixing, which was favorable for DO supply. An examination of surface air-sea $\mathrm{CO}_{2}$ fluxes revealed that the Louisiana shelf acted as weak source of atmospheric $\mathrm{CO}_{2}$ in July 
2009 in contrast to a weak sink in August 2007. The slope of the DO and DIC relationship in August 2007 was comparable to the Redfield stoichiometry of 1.3 for the $\mathrm{O} / \mathrm{C}$ ratio and was an indication of the influence of respiration in the bottom waters. The slope of the DO and DIC relationship as well as the $\delta^{13} \mathrm{C}_{\text {DIC }}$ values in bottom water were affected by mixing during upwelling-favorable wind forcing in July 2009. After removing mixing effects, patterns of $\delta^{13} \mathrm{C}_{\text {DIC }}$ also provided evidence that the source of DIC released via respiration was of marine origin in both August 2007 and July 2009. Our results provide clear evidence that wind direction and shelf circulation on the Louisiana shelf play a major role in the distribution of salinity, biological communities, community metabolism, and biogeochemical properties, such as chl- $a$, DO, $p \mathrm{CO}_{2}$, and DIC values. For this highly anthropogenically influenced system, we suggest that anomalous weather events such as that observed in July 2009 may become more frequent under future climatic conditions with major consequences for carbon processes.

\section{Acknowledgements}

We thank the captains and their crews of the OSV Bold and R/V Cape Hatteras for their support in field sampling. Austin Todd provided many helpful comments. This work was supported by the National Science Foundation (OCE-0752110 and OCE- 0752254), the National Aeronautics and Space Administration (NNX10AU06G, NX10AU78G, NNH14AY07I, NNX14AO73G), and the BP-funded Gulf of Mexico Research Initiative RFP-II award (GoMRI-020). 


\section{References}

Ávila-López M. C., J. M. Hernández-Ayón, V. F. Camacho-Ibar, J. M. Sandoval-Gil, A. Mejía-Trejo, and I. Pacheco-Ruiz. Air-Sea $\mathrm{CO}_{2}$ fluxes and NEP changes in a Baja California Coastal Lagoon during the anomalous North Pacific warm conditions in 2014. Cont, Shelf, Res (under revision).

Barron Jr, C. N., \& Vastano, A. C. (1994). Satellite observations of surface circulation in the northwestern Gulf of Mexico during March and April 1989. Cont. Shelf Res., 14(6), 607-628. doi:10.1016/02784343(94)90109-0

Bauer, J. E., and T. S. Bianchi (2011). Dissolved organic carbon cycling and transformation, edited by E. Wolanski and D. B. T.-T. on E. and C. S. McLusky, pp. 7-67, Academic Press, Waltham.

Bauer, J. E., Cai, W.-J., Raymond, P. A., Bianchi, T. S., Hopkinson, C. S., \& Regnier, P. A. G. (2013). The changing carbon cycle of the coastal ocean. Nature, 504(7478), 61-70. doi:10.1038/nature12857

Bianchi, T S, DiMarco, S. F., Cowan Jr, J. H., Hetland, R. D., Chapman, P., Day, J. W., \& Allison, M. A. (2010). The science of hypoxia in the Northern Gulf of Mexico: A review. Sci. Total Environ., 408(7), 1471-1484.

Bianchi, Thomas S, Mitra, S., \& McKee, B. A. (2002). Sources of terrestrially-derived organic carbon in lower Mississippi River and Louisiana shelf sediments: implications for differential sedimentation and transport at the coastal margin. Mar. Chem., 77(2-3), 211-223. doi:http://dx.doi.org/10.1016/S0304-4203(01)00088-3

Brandes, J. A. (2009). Rapid and precise $\delta^{13} \mathrm{C}$ measurement of dissolved inorganic carbon in natural waters using liquid chromatography coupled to an isotope-ratio mass spectrometer. Limnol. Oceanogr. Meth., 7(11), 730-739. doi:10.4319/lom.2009.7.730 
Cai, W.-J. (2003). Riverine inorganic carbon flux and rate of biological uptake in the Mississippi River plume. Geophys. Res. Lett., 30(2), 1032. doi:10.1029/2002GL016312

Cai, W.-J. (2011). Estuarine and coastal ocean carbon paradox: $\mathrm{CO}_{2}$ sinks or sites of terrestrial carbon incineration? Annu. Rev. Mar. Sci., 3(1), 123-145. doi:doi:10.1146/annurev-marine-120709-142723

Cai, W.-J., Dai, M., \& Wang, Y. C. (2006). Air-sea exchange of carbon dioxide in ocean margins: A province-based synthesis. Geophys. Res. Lett., 33(12), L12603.

Cai, W.-J., Hu, X., Huang, W.-J., Jiang, L.-Q., Wang, Y., Peng, T.-H., \& Zhang, X. (2010). Alkalinity distribution in the western North Atlantic Ocean margins. J. Geophys. Res., 115(C8), C08014. doi:10.1029/2009jc005482

Cantoni, C., Luchetta, A., Celio, M., Cozzi, S., Raicich, F., \& Catalano, G. (2012). Carbonate system variability in the Gulf of Trieste (North Adriatic Sea). Estuar. Coast. Shelf S., 115(10), 51-62. doi:10.1016/j.ecss.2012.07.006

Chakraborty, S., \& Lohrenz, S. E. (2015). Phytoplankton community structure in the river-influenced continental margin of the northern Gulf of Mexico. Mar. Ecol. Prog. Ser., 521, 31-47.

Chang, Y.-L., \& Oey, L.-Y. (2010). Why can wind delay the shedding of Loop Current eddies? J. Phys. Oceanogr., 40(11), 2481-2495. doi:10.1175/2010JPO4460.1

Chen, C.-T. A., \& Borges, A. V. (2009). Reconciling opposing views on carbon cycling in the coastal ocean: Continental shelves as sinks and near-shore ecosystems as sources of atmospheric $\mathrm{CO}_{2}$. Deep Sea Res. PT. II, 56(8-10), 578-590.

Chen, X., Lohrenz, S. E., \& Wiesenburg, D. A. (2000). Distribution and controlling mechanisms of primary production on the Louisiana-Texas continental shelf. J. Mar. Syst., 25(2), 179-207. 
Chen X., D. Pan, Y. Bai, Y. Kangd, X. He, B. Tao, C.-T. A. Chen. Estimation of typhoon-enhanced primary production in the South China Sea: A Comparison with the Western North Pacific, Cont, Shelf, Res. (under revision).

Cho, K., Reid, R. O., \& Nowlin Jr., W. D. (1998). Objectively mapped stream function fields on the Texas-Louisiana shelf based on 32 months of moored current meter data. J. Geophys. Res., 103.

Cochrane, J. D., \& Kelly, F. J. (1986). Low-frequency circulation on the Texas-Louisiana continental shelf. J. Geophys. Res., Oceans and atmospheres, 91(9), 10645-10659. doi:10.1029/JC091iC09p10645

Del Castillo, C. E., Coble, P. G., Conmy, R. N., Müller-Karger, F. E., Vanderbloemen, L., \& Vargo, G. A. (2001). Multispectral in situ measurements of organic matter and chlorophyll fluorescence in seawater: Documenting the intrusion of the Mississippi River plume in the West Florida Shelf. Limnol. Oceanogr., 46(7), 1836-1843.

DeLaune, R. D. (1986). The use of $\delta^{13} \mathrm{C}$ signature of C-3 and C-4 plants in determining past depositional environments in rapidly accreting marshes of the Mississippi River deltaic plain, Louisiana, U.S.A. Chem. Geol., 59, 315-320. doi:http://dx.doi.org/10.1016/0168-9622(86)90080-1

Doney, S. C., Ruckelshaus, M., Emmett Duffy, J., Barry, J. P., Chan, F., English, C. A., ... Talley, L. D. (2011). Climate change impacts on marine ecosystems. Annu. Rev. Mar. Sci., 4(1), 11-37. doi:10.1146/annurev-marine-041911-111611

Dubois, K. D., Lee, D., \& Veizer, J. (2010). Isotopic constraints on alkalinity, dissolved organic carbon, and atmospheric carbon dioxide fluxes in the Mississippi River. J. Geophys. Res., 115(G2), G02018. doi:10.1029/2009jg001102 
Evans, M. A., \& Scavia, D. (2011). Forecasting hypoxia in the Chesapeake Bay and Gulf of Mexico: model accuracy, precision, and sensitivity to ecosystem change. Environ. Res. Lett., 6(1), 15001.

Feng, Y., Fennel, K., Jackson, G. A., DiMarco, S. F., \& Hetland, R. D. (2014). A model study of the response of hypoxia to upwelling-favorable wind on the northern Gulf of Mexico shelf. J. Mar. Syst., 131, 63-73. doi:10.1016/j.jmarsys.2013.11.009

Fichot, C. G., Lohrenz, S. E., \& Benner, R. (2014). Pulsed, cross-shelf export of terrigenous dissolved organic carbon to the Gulf of Mexico. J. Geophys. Res. Oceans, 119(2), 1176-1194. doi:10.1002/2013JC009424

Forrest, D. R., Hetland, R. D., \& DiMarco, S. F. (2011). Multivariable statistical regression models of the areal extent of hypoxia over the Texas-Louisiana continental shelf. Environ. Res. Lett., 6(4), 45002.

Fry, B., Justić, D., Riekenberg, P., Swenson, E. M., Turner, R. E., Wang, L., ... Boyd, B. (2014). Carbon dynamics on the Louisiana continental shelf and cross-shelf feeding of hypoxia. Estuaries Coasts. doi:10.1007/s12237-014-9863-9

Guo, X., Cai, W.-J., Huang, W.-J., Wang, Y., Chen, F., Murrell, M. C., .. Culp, R. (2012). Carbon dynamics and community production in the Mississippi River plume. Limnol. Oceanogr., 57(1), 117.

Hetland, R. D., \& DiMarco, S. F. (2008). How does the character of oxygen demand control the structure of hypoxia on the Texas-Louisiana continental shelf? J. Marine Systems, 70(1-2), 49-62.

Ho, D. T., Law, C. S., Smith, M. J., Schlosser, P., Harvey, M., \& Hill, P. (2006). Measurements of air-sea gas exchange at high wind speeds in the Southern Ocean: Implications for global parameterizations. Geophys. Res. Lett., 33(16), L16611. doi:10.1029/2006gl026817 
Hu, X., Cai, W.-J., Rabalais, N. N., \& Xue, J. (In press). Coupled oxygen and dissolved inorganic carbon dynamics in coastal ocean and its use as a potential indicator for detecting water column oil degradation. Deep Sea Res. PT. II. doi:http://dx.doi.org/10.1016/j.dsr2.2014.01.010

Huang, W.-J., Cai, W.-J., Powell, R. T., Lohrenz, S. E., Wang, Y., Jiang, L. Q., \& Hopkinson, C. S. (2012). The stoichiometry of inorganic carbon and nutrient removal in the Mississippi River plume and adjacent continental shelf. Biogeosciences, 9(7), 2781-2792. doi:10.5194/bg-9-2781-2012

Huang, W.-J., Cai, W.-J., Wang, Y., Lohrenz, S. E., \& Murrell, M. C. (2015). The carbon dioxide system on the Mississippi River-dominated continental shelf in the northern Gulf of Mexico: 1. Distribution and air-sea $\mathrm{CO}_{2}$ flux. J. Geophys. Res. Oceans, 120, doi:10.1002/2014JC010498

Huang, W.-J., Castelao, R. M., \& Lohrenz, S. E. (2013). Effects of a wind-driven cross-shelf large river plume on biological production and $\mathrm{CO}_{2}$ uptake on the Gulf of Mexico during spring. Limnol. Oceanogr., 58(5), 1727-1735. doi:10.4319/1o.2013.58.5.1727

Huang, W.-J., Wang, Y., \& Cai, W.-J. (2012). Assessment of sample storage techniques for total alkalinity and dissolved inorganic carbon in seawater. Limnol. Oceanogr. Meth., 10, 711-717. doi:10.4319/lom.2012.10.711

Jiang, L.-Q., Cai, W.-J., Wang, Y., Wanninkhof, R., \& Lüger, H. (2008). Air-sea $\mathrm{CO}_{2}$ fluxes on the U.S. South Atlantic Bight: Spatial and seasonal variability. J. Geophys. Res., 113, C07019. doi:10.1029/2007jc004366

Jones, E.B., Wiggert, J.D., 2015. Characterization of a high chlorophyll plume in the northeastern Gulf of Mexico. Remote Sens. Environ. doi:10.1016/j.rse.2014.11.019

Lentz, S. J., \& Fewings, M. R. (2012). The wind- and wave-driven inner-shelf circulation. Annu. Rev. Mar. Sci., 4(1), 317-343. doi:10.1146/annurev-marine-120709-142745 
Lehrter, J.C., Murrell, M.C., Kurtz, J.C., 2009. Interactions between freshwater input, light, and phytoplankton dynamics on the Louisiana continental shelf. Cont. Shelf Res. 29, 1861-1872.

Lohrenz, S.E., Fahnenstiel, G.L., Redalje, D.G., Lang, G.A., Dagg, M.J., Whitledge, T.E., Dortch, Q., 1999. Nutrients, irradiance, and mixing as factors regulating primary production in coastal waters impacted by the Mississippi River plume. Cont. Shelf Res. 19, 1113-1141.

Lohrenz, S. E., and W.-J. Cai (2006), Satellite ocean color assessment of air-sea fluxes of $\mathrm{CO}_{2}$ in a riverdominated coastal margin, Geophys. Res. Lett., 33(1), L01601.

Lohrenz, S. E., Cai, W.-J., Chen, F., Chen, X., \& Tuel, M. (2010). Seasonal variability in air-sea fluxes of $\mathrm{CO}_{2}$ in a river-influenced coastal margin. J. Geophys. Res., 115(C10), C10034. doi:10.1029/2009jc005608

Lui H.-K., C.-T. A. Chen, J. Lee, S.-L. Wang, G.-C.. Gong, Y. Bai, and X. He, Acidifying intermediate water accelerates the acidification of seawater on shelves: an example of the East China Sea. Cont, Shelf, Res (under revision).

Maske, H., Medrano, R. C., Castro, A. T., Mercado, A. J., Jauregui, C. O. A., Castro, G. G., \& Ochoa, J. (2010). Inorganic carbon and biological oceanography above a shallow oxygen minimum in the entrance to the Gulf of California in the Mexican Pacific. Limnol. Oceanogr., 55(2), 481-491. doi:10.4319/lo.2010.55.2.0481

McIsaac, G. F., David, M. B., Gertner, G. Z., \& Goolsby, D. A. (2001). Eutrophication: Nitrate flux in the Mississippi River. Nature, 414(6860), 166-167. 
Nababan, B., Muller-Karger, F. E., Hu, C., \& Biggs, D. C. (2011). Chlorophyll variability in the northeastern Gulf of Mexico. Int. J. Remote Sens., 32(23), 8373-8391.

Nowlin, W. D., A. E. Jochens, S. F. DiMarco, R. O. Reid, and M. K. Howard (2005), Low-frequency circulation over the Texas-Louisiana continental shelf, in Circulation in the Gulf of Mexico: Observations and Models, pp. 219-240, American Geophysical Union.

Ohlmann, J. C., \& Niiler, P. P. (2005). Circulation over the continental shelf in the northern Gulf of Mexico. Prog. Oceanogr., 64(1), 45-81.

Rabouille, C. et al. (2008), Comparison of hypoxia among four river-dominated ocean margins: The Changjiang (Yangtze), Mississippi, Pearl, and Rhône rivers, Cont. Shelf Res., 28(12), 1527-1537.

Rabalais, N. N., Diaz, R. J., Levin, L. A., Turner, R. E., Gilbert, D., \& Zhang, J. (2010). Dynamics and distribution of natural and human-caused hypoxia. Biogeosciences, 7(2), 585-619. doi:10.5194/bg7-585-2010

Raymond, P. A., Oh, N.-H., Turner, R. E., \& Broussard, W. (2008). Anthropogenically enhanced fluxes of water and carbon from the Mississippi River. Nature, 451(7177), 449-452.

Redfield, A. C. (1958), The biological control of chemical factors in the environment, Am. Sci., 46, 205221.

Romanek, C. S., Grossman, E. L., \& Morse, J. W. (1992). Carbon isotopic fractionation in synthetic aragonite and calcite: Effects of temperature and precipitation rate. Geochim. Cosmochim. Ac., 56(1), 419-430. doi:http://dx.doi.org/10.1016/0016-7037(92)90142-6

Shi, W., \& Wang, M. (2009). Satellite observations of flood-driven Mississippi River plume in the spring of 2008. Geophys. Res. Lett., 36(7), L07607. doi:10.1029/2009gl037210 
Smith, S. R., \& Jacobs, G. A. (2005). Seasonal circulation fields in the northern Gulf of Mexico calculated by assimilating current meter, shipboard ADCP, and drifter data simultaneously with the shallow water equations. Cont. Shelf Res., 25(2), 157-183.

Strauss, J., Grossman, E. L., \& DiMarco, S. F. (2012). Stable isotope characterization of hypoxiasusceptible waters on the Louisiana shelf: Tracing freshwater discharge and benthic respiration. Cont. Shelf Res., 47, 7-15. doi:10.1016/j.csr.2012.07.020

Turner, R E, Rabalais, N. N., \& Justić, D. (2012). Predicting summer hypoxia in the northern Gulf of Mexico: Redux. Mar. Pollut. Bull., 64(2), 319-324. doi:10.1016/j.marpolbul.2011.11.008

Turner, R Eugene, Rabalais, N. N., \& Justic, D. (2008). Gulf of Mexicohypoxia: Alternate states and a legacy. Environ. Sci. Technol., 42(7), 2323-2327.

Wang, W., W. D. Nowlin, and R. O. Reid (1998), Analyzed surface meteorological fields over the Northwestern Gulf of Mexico for 1992-94: Mean, seasonal, and monthly patterns, Mon. Weather Rev., 126(11), 2864-2883, doi:10.1175/1520-0493(1998)126<2864:asmfot>2.0.co;2.

Wiseman, W. J., Rabalais, N. N., Turner, R. E., Dinnel, S. P., \& MacNaughton, A. (1997). Seasonal and interannual variability within the Louisiana coastal current: stratification and hypoxia. J. Mar. Syst., 12(1-4), 237-248.

Xue, Z., He, R., Fennel, K., Cai, W. J., Lohrenz, S., \& Hopkinson, C. (2013). Modeling ocean circulation and biogeochemical variability in the Gulf of Mexico. Biogeosciences, 10, 7219-7234. doi: 10.5194/bg-10-7219-2013

York, D. (1966) Least-squares fitting of a straight line, Can. J. Phys., 44, 1079-1086, doi:10.1139/p66090 
Zhang, X., Hetland, R. D., Marta-Almeida, M., \& DiMarco, S. F. (2012). A numerical investigation of the Mississippi and Atchafalaya freshwater transport, filling and flushing times on the Texas-Louisiana Shelf. J. Geophys. Res., 117(C11), C11009. doi:10.1029/2012jc008108 

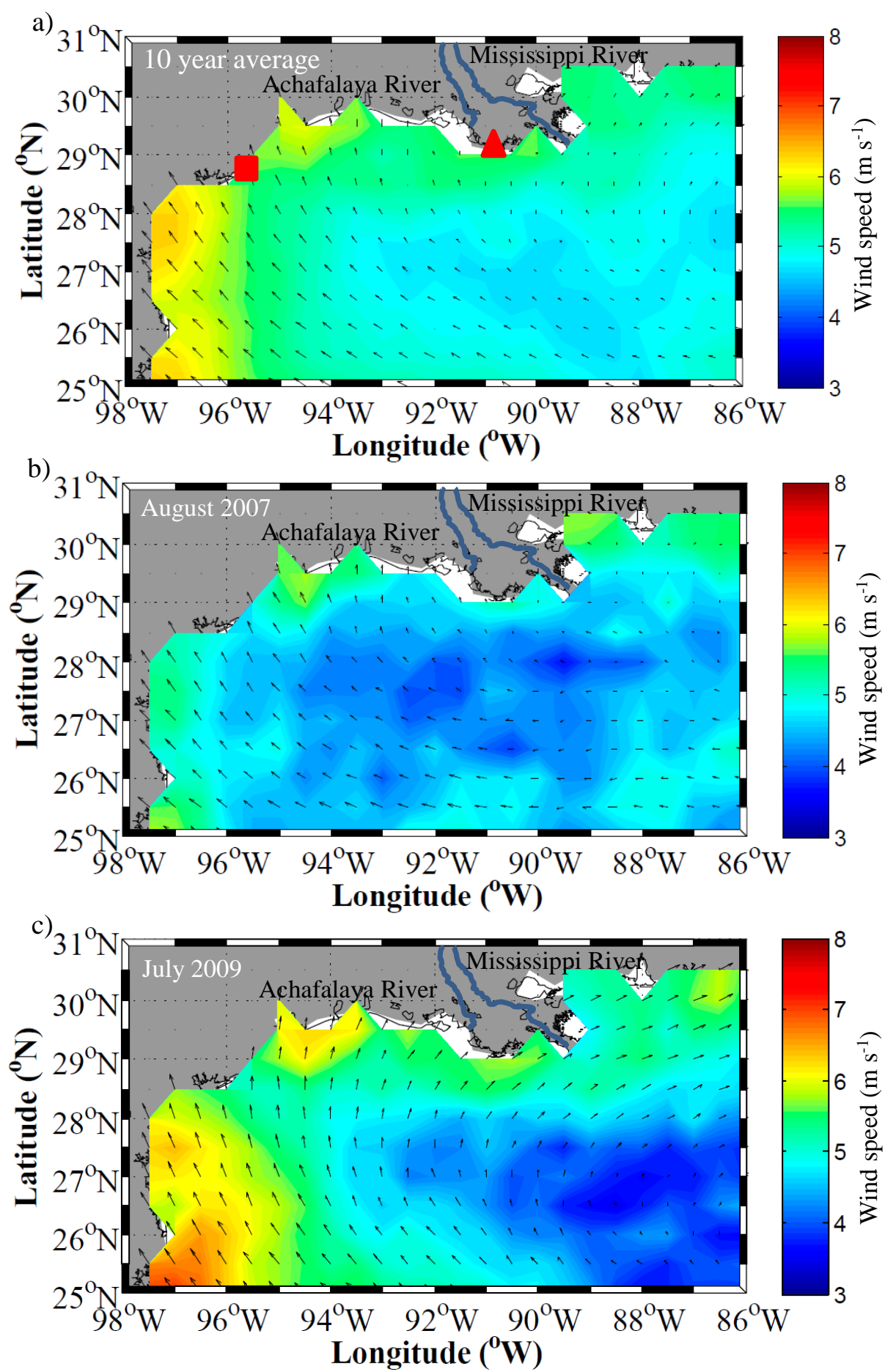

Figure 1. Spatial variation of wind forcing over the Gulf of Mexico. The average of July and August wind forcing from 2002 to 2009 (a) showed generally southerly or southeasterly wind over the northern gulf. Similar wind forcing was observed in August 2007 (b) in contrast to southwesterly wind was observed at Coccodrie, Louisiana in July 2009 (c). The triangle marker in 
panel (a) is the NOAA station LUML1 at Coccodrie, Louisiana and the square maker is the NOAA buoy off the Galveston, Texas. 


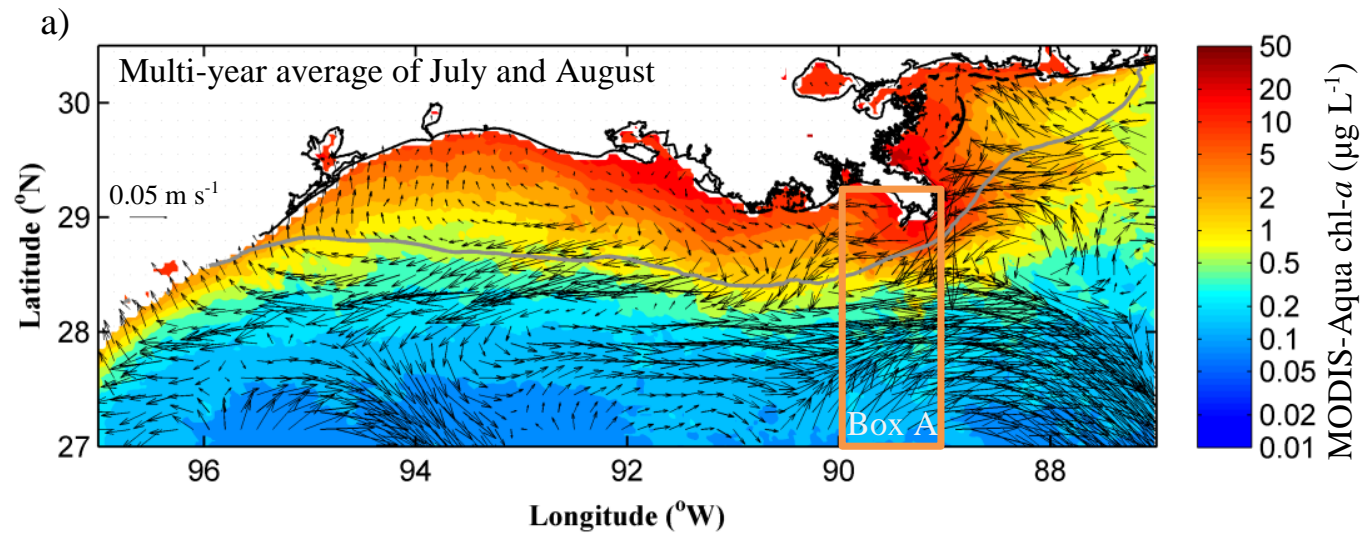

b)
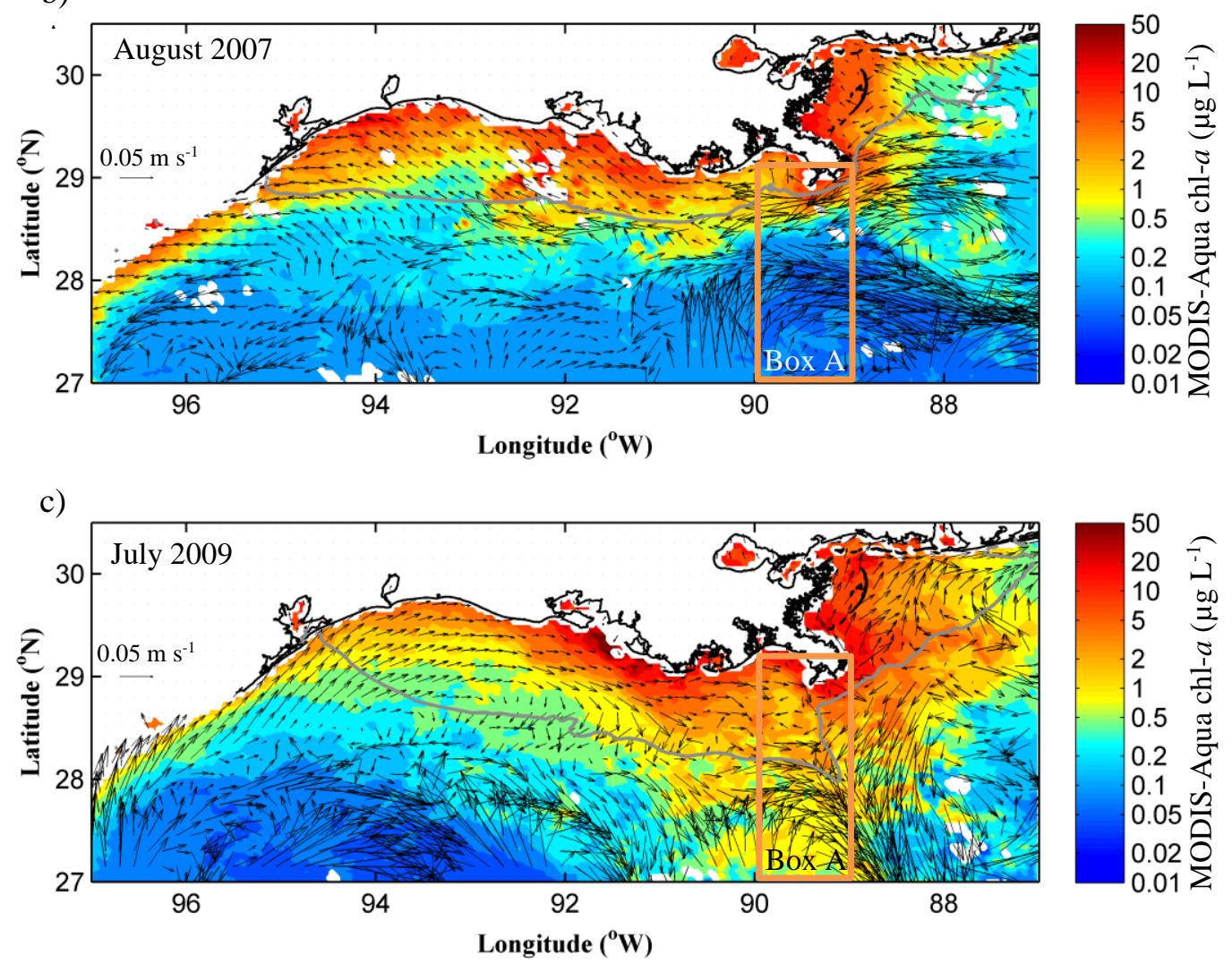

Figure 2. Trajectories of river plumes represented by MODIS-Aqua chl- $a$ concentrations. The distribution of the average of MODIS-Aqua chl- $a$ concentrations in July and August from 2002 to 2010 (a) was analogous to the average in our sampling period in August 2007 (b), displaying an alongshore river plume trajectory to the north of $28^{\circ} \mathrm{N}$ and a few scattered chl- $a$ patches off the south of river delta. In contrast, the monthly chl- $a$ distribution in July 2009 was generally confined to the east of $91.5^{\circ} \mathrm{W}$, with a high concentration patch off Atchafalaya Bay, and extended to offshore (c). In addition, we adopted HYCOM simulated surface currents during July and August from 2003 to 2010 to demonstrate the synoptic surface current (arrow markers 
represent the direction and strength) in panel (a) and during our sampling periods in panel (b) and (c). Gray lines are the contour line of HYCOM simulated salinity 33. MODIS-Aqua chl- $a$ concentrations from shelf to open Gulf (Box A in orange color) were compared later. 


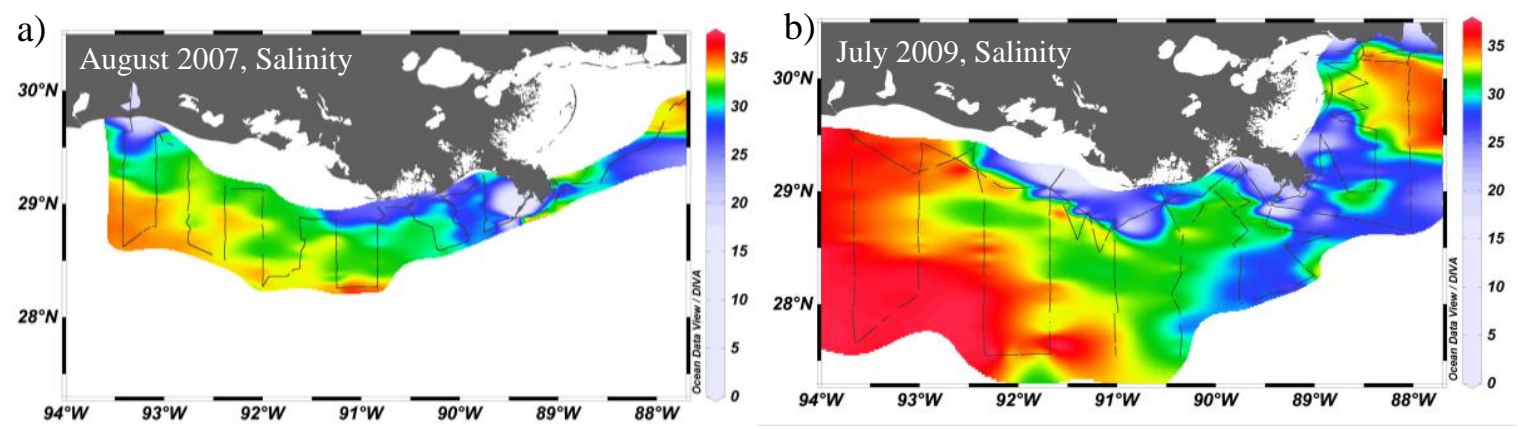

Figure 3. Distribution of surface seawater salinity. Lower salinity waters were distributed on the inner shelf, and higher salinity (>33) waters were distributed to the west on the outer shelf in August 2007 (a). Low salinity waters were distributed mostly to the eastern shelf (both inner and outer); high salinity waters were observed on the inner western shelf, except the Atchafalaya Bay and its adjacent areas in July 2009 (b). Particularly, high salinity waters were observed on the inner shelf to the west of $93.0^{\circ} \mathrm{W}$. 


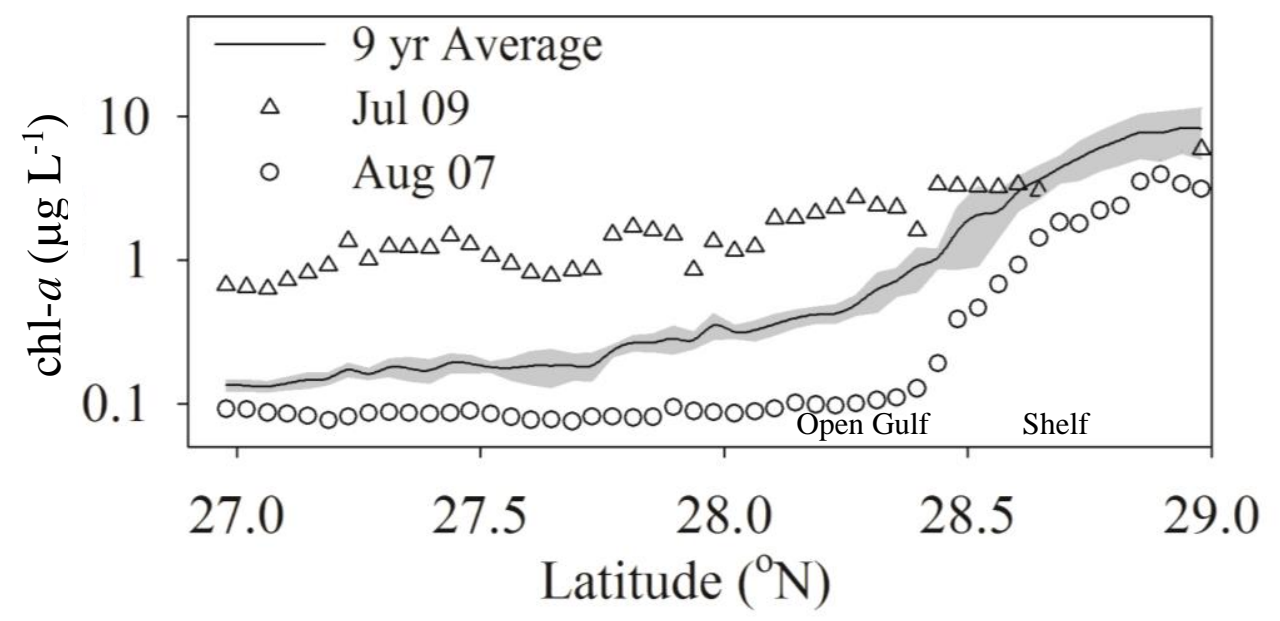

Figure 4. Latitudinal variations of MODIS-Aqua chl- $a$ off the river delta. The average of July and August over nine years (black line with \pm 1 standard deviation in gray zone) was high on the shelf to $28.5^{\circ} \mathrm{N}$ and gradually decreased to $0.15 \mu \mathrm{g} \mathrm{L}^{-1}$ on the open gulf. High chl-a concentrations were observed in the open gulf in July 2009 (triangles) but were only observed on the shelf in August 2007 (circles). 

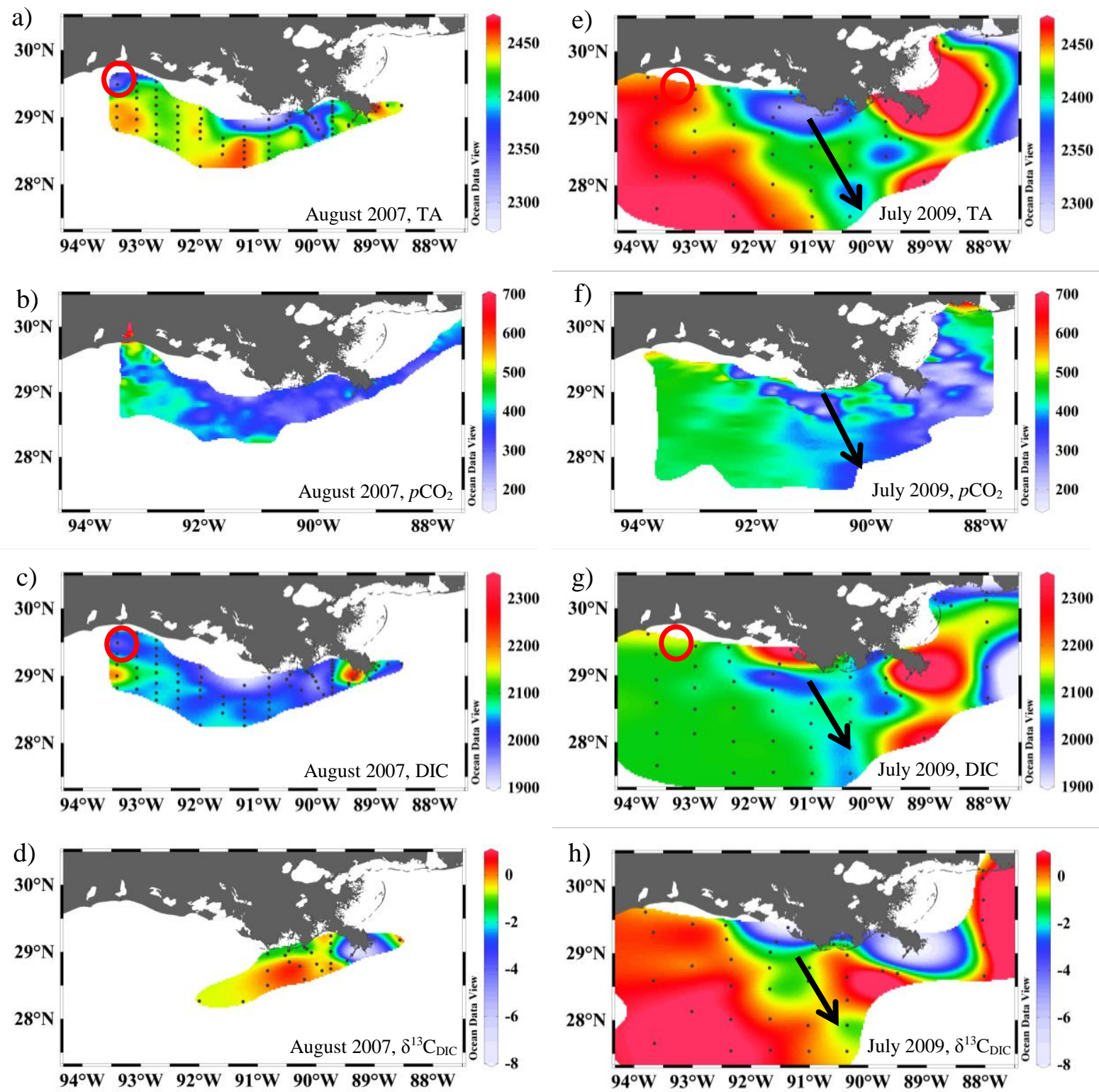

Figure 5. Distributions of sea surface TA $(\mu \mathrm{M}), p \mathrm{CO}_{2}$ ( $\left.\mu \mathrm{atm}\right)$, DIC $(\mu \mathrm{M})$, and $\delta^{13} \mathrm{C}_{\mathrm{DIC}}(\%)$. Sea surface TA (a), $p \mathrm{CO}_{2}$ (b), DIC (c), and $\delta^{13} \mathrm{C}_{\mathrm{DIC}}$ (d) were generally lower on the inner compared to the outer shelf in August 2007, except the waters in the Mississippi River channel and near the lakes or bays showed high TA and $p \mathrm{CO}_{2}$. Despite three small patches immediately off Mobile Bay, Atchafalaya Bay, and the Mississippi River Delta, sea surface TA (e), $p \mathrm{CO}_{2}$ (f), DIC (g), and $\delta^{13} \mathrm{C}_{\mathrm{DIC}}$ (h) were lower to the east of $91.5^{\circ} \mathrm{W}$ compared to the values to the west of $91.5^{\circ} \mathrm{W}$, respectively. Red circles indicate the location of the inner shelf to the west of $93^{\circ} \mathrm{W}$ and black arrows show low values extending from the inner to outer shelves. 


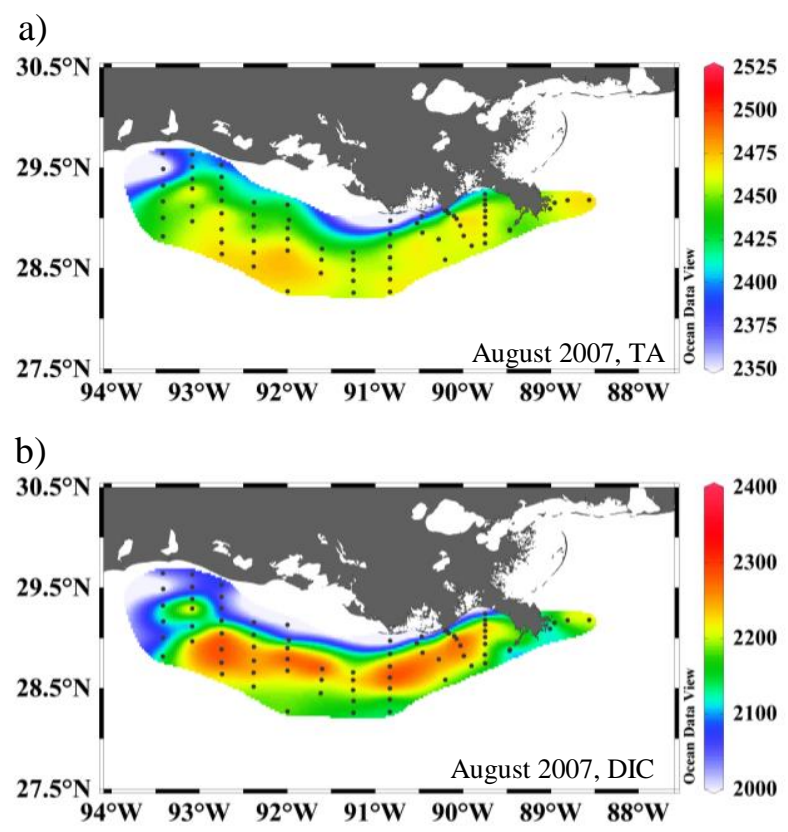

d)
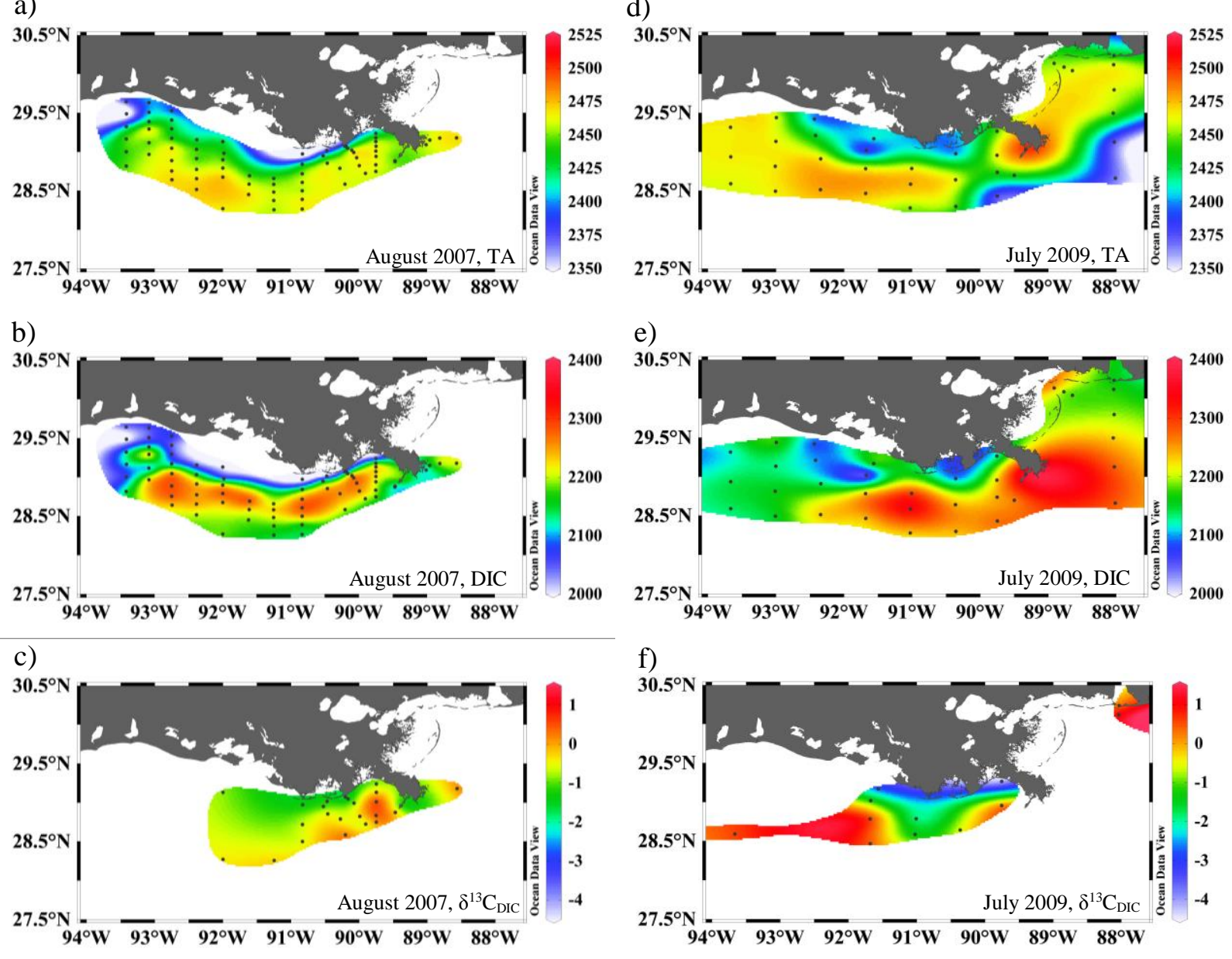

e)
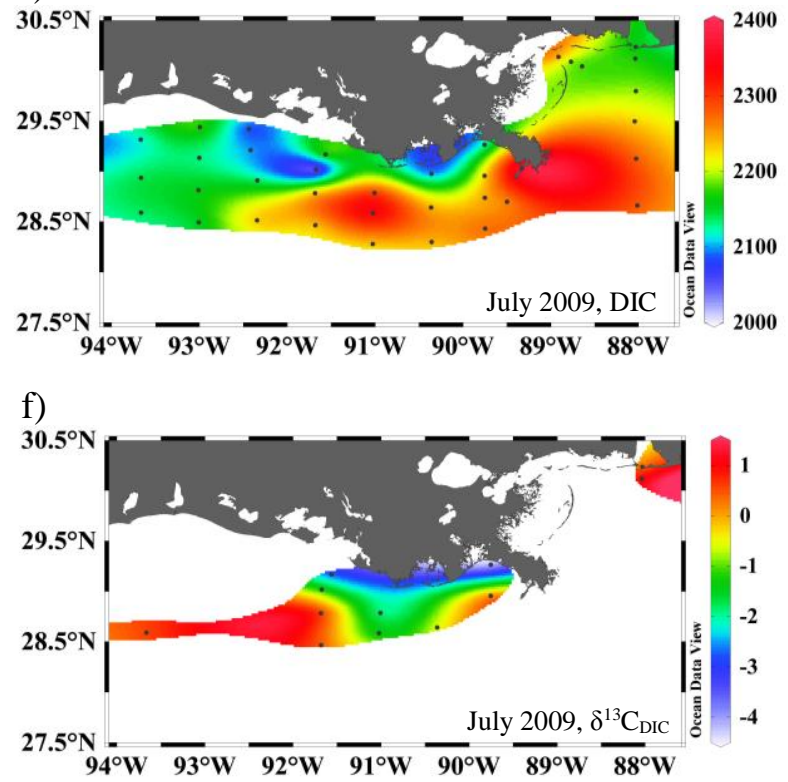

Figure 6. Distributions of TA $(\mu \mathrm{M})$, DIC $(\mu \mathrm{M})$, and $\delta^{13}$ CDIC (\%o) in bottom water. TA (a), DIC (b), and $\delta^{13} \mathrm{C}_{\mathrm{DIC}}$ (c) values in the bottom water were lower on the inner shelf and were higher on the middle and outer shelves in August 2007. Despite the fact that such cross-shelf gradients can also be observed in the region right south to Atchafalaya Bay in July 2009, TA (d) and DIC (e) values were higher to the west of $93^{\circ} \mathrm{W} . \delta^{13} \mathrm{C}_{\text {DIC }}$ (f) values were lower on the inner shelf and displayed lower values than the ones in August 2007 along $91^{\circ} \mathrm{W}$. 
a)

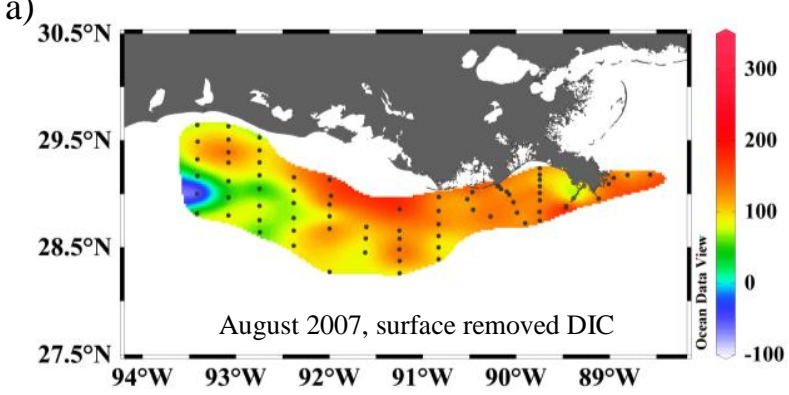

b)

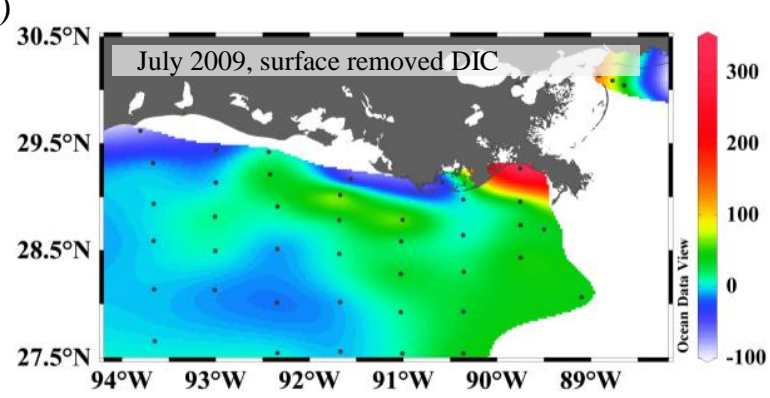

c)

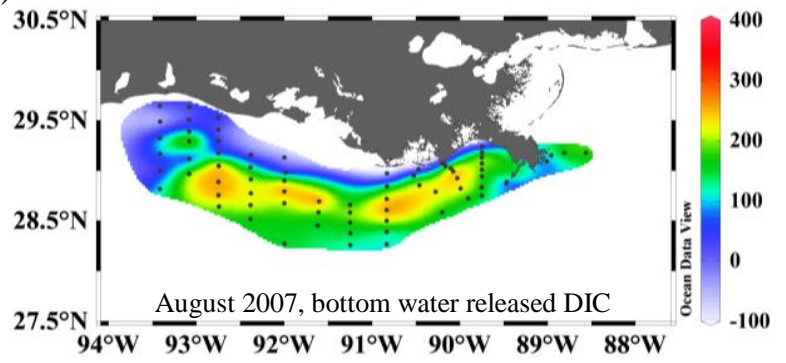

d)

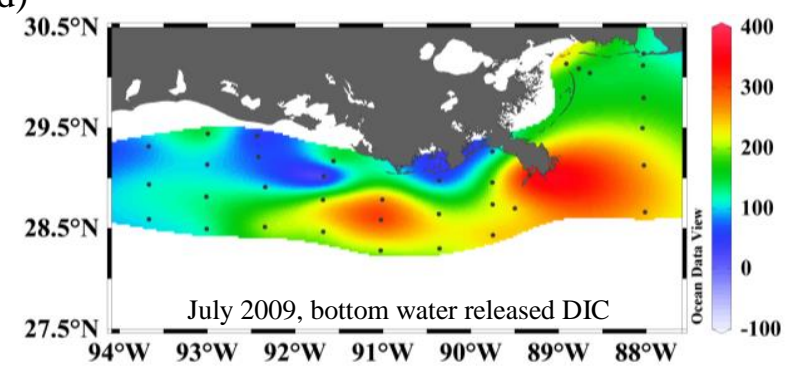

Figure 7. Distributions of surface water-removed DIC and bottom water-released DIC concentrations $(\mu \mathrm{M})$. Surface DIC removals were generally higher in August 2007 (a) than those in July 2009 (b) and the difference between them was higher to the east of $91.5^{\circ} \mathrm{W}$ (c). In the bottom water, released DIC was high alongshore around the middle shelf to the west of $91.5^{\circ} \mathrm{W}$ in August 2007 (c) and such high DIC release was not observed to the west of $91.5^{\circ} \mathrm{W}$ in July 2009 (d). 

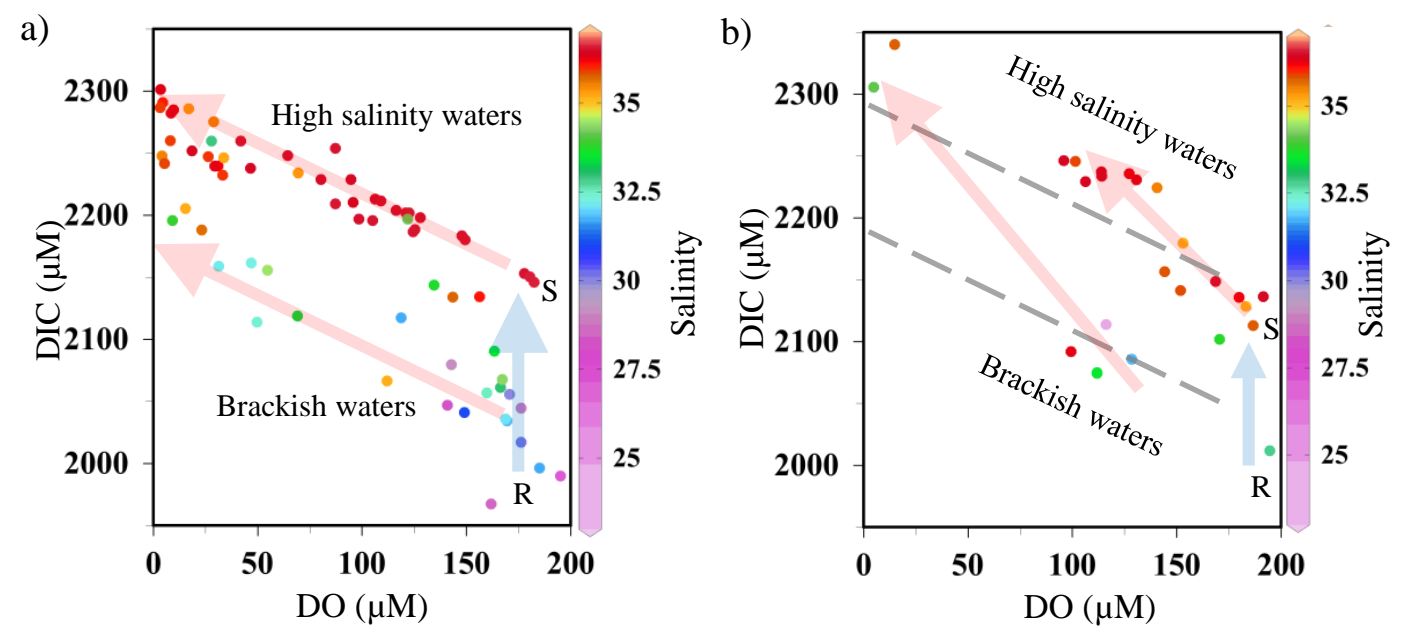

Figure 8. The relationships between DO and DIC. In August 2007, the relationship between DO and DIC in the bottom water can be observed in brackish waters and seawater individually (a), which were separated by an alongshore isobath zone between 10 and $20 \mathrm{~m}$. The slopes of the DOto-DIC relationship $\left(1.0 \pm 0.2, \mathrm{R}^{2}=0.826\right.$ for brackish water; and $1.2 \pm 0.1, \mathrm{R}^{2}=0.836$ for high salinity waters) were both close to the estimation of Redfield respiration (represented by two red arrows in b). In July 2009, the slopes of the relationship between DO and DIC were higher than those in August 2007 and also higher than Redfield-ratio predicted lines (gray dash lines). 


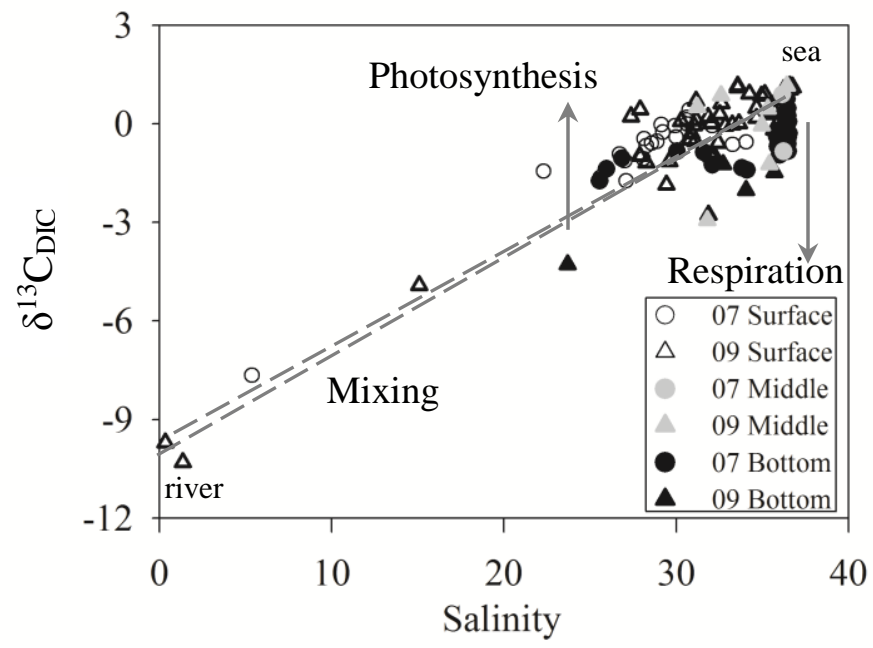

Figure 9. The relationship between salinity and $\delta^{13} \mathrm{C}_{\mathrm{DIC}}(\%)$. In surface waters (open markers), $\delta^{13} \mathrm{C}_{\text {DIC }}$ values were generally higher than the two mixing lines between river and sea end-members, suggesting the effect of photosynthesis on surface DIC concentrations. Such photosynthesis signal can also be observed in some samples from bottom waters (closed markers). However, other samples with lower $\delta^{13} \mathrm{C}_{\mathrm{DIC}}$ values suggested respiration. Particularly, samples showed much lower $\delta^{13} \mathrm{C}_{\text {DIC }}$ values in July 2009 than in August 2007 in the salinity range between 23 to 35 in bottom waters. 
Table 1. Differences in areal-weighted averages of $p \mathrm{CO}_{2}$, DIC concentration, air-sea $\mathrm{CO}_{2}$ fluxes, and surface removed and bottom released DIC between August 2007 and July 2009.

\begin{tabular}{crrrr}
\hline & $\begin{array}{r}\text { August 2007 } \\
(\mathrm{a})\end{array}$ & $\begin{array}{r}\text { July 2009 } \\
(\mathrm{b})\end{array}$ & $\begin{array}{r}\text { Difference } \\
(\mathrm{c})=(\mathrm{b})-(\mathrm{a})\end{array}$ & Units \\
\hline surface $p \mathrm{CO}_{2}$ & $347.8 \pm 49.7$ & $403.7 \pm 70.1$ & $55.9 \pm 119.8$ & $\mu \mathrm{atm}$ \\
Surface DIC & $2019.7 \pm 67.2$ & $2103.8 \pm 125.9$ & $84.1 \pm 193.1$ & $\mu \mathrm{M}$ \\
Bottom DIC & $2123.5 \pm 82.8$ & $2173.6 \pm 72.7$ & $50.1 \pm 155.5$ & $\mu \mathrm{M}$ \\
Air-sea CO $\mathrm{C}_{2}$ flux & $-2.0 \pm 0.2$ & $1.4 \pm 0.1$ & $3.4 \pm 0.3$ & $\mathrm{mmol} \mathrm{m}^{-2} \mathrm{~d}^{-1}$ \\
Surface removed DIC & $106.8 \pm 39.0$ & $25.0 \pm 63.7$ & $-81.8 \pm 102.7$ & $\mu \mathrm{M}$ \\
Bottom released DIC & $22.0 \pm 88.2$ & $90.3 \pm 69.2$ & $68.3 \pm 157.4$ & $\mu \mathrm{M}$ \\
\hline
\end{tabular}


Table A, Endmembers for the three-endmember mixing model. The river end-member of $\delta^{13} \mathrm{C}_{\mathrm{DIC}}$ in August 2007 was lacking and was replaced by the values from July 2009.

\begin{tabular}{lrrrrr}
\hline \multicolumn{7}{c}{ End-member } & Salinity & $\begin{array}{c}\mathrm{TA} \\
\mu \mathrm{mol} \mathrm{kg}^{-1}\end{array}$ & $\begin{array}{c}\mathrm{DIC} \\
\mu \mathrm{mol} \mathrm{kg}^{-1}\end{array}$ & $\begin{array}{c}\mathrm{NO}_{3} \\
\mu \mathrm{mol} \mathrm{kg}^{-1}\end{array}$ & $\begin{array}{c}\delta^{13} \mathrm{C} \\
\% \text { \% }\end{array}$ \\
\hline \multicolumn{7}{c}{2007 cruise } \\
Mississippi River & 0.1 & 2420.0 & 2450.0 & 51.4 & -10.7 \\
Atchafalaya River & 0.1 & 1620.0 & 1650.0 & 35.0 & -9.7 \\
Sea & 36.04 & 2399.3 & 2082.8 & 2.3 & 0.65 \\
\multicolumn{7}{c}{ July 2009 cruise } \\
Mississippi River & 0.1 & 2140.0 & 2170.0 & 100.7 & -10.7 \\
Atchafalaya River & 0.1 & 1580.0 & 1610.0 & 45.7 & -9.7 \\
Sea & 36.75 & 2424.7 & 2055.2 & 0.7 & 1.3 \\
\hline
\end{tabular}


Table $2, \delta^{13} \mathrm{C}_{\text {DIC }}$ in hypoxic waters.

\begin{tabular}{llllrllllrr}
\hline Cruise & Station & $\begin{array}{c}\text { Latitude } \\
{ }^{\circ} \mathrm{N}\end{array}$ & $\begin{array}{c}\text { Longitude } \\
{ }^{\circ} \mathrm{W}\end{array}$ & $\begin{array}{c}\text { Depth } \\
\mathrm{m}\end{array}$ & Sal. & $\begin{array}{c}\text { DIC } \\
\mu \mathrm{M}\end{array}$ & $\begin{array}{c}\delta^{13} \mathrm{C}_{\text {DIC }} \\
\% \text { 保 }\end{array}$ & $\begin{array}{c}\delta^{13} \mathrm{C}_{\text {resp }} \\
\% \text { \% }\end{array}$ & $\begin{array}{r}\text { DO } \\
\mu \mathrm{M}\end{array}$ \\
\hline GM0708 & A04 & 29.133 & 89.750 & 18 & 36.16 & 2239.7 & -0.33 & -19.9 & 30.9 \\
GM0708 & A06 & 29.010 & 89.751 & 25 & 36.22 & 2267.1 & -0.85 & -24.5 & 24.7 \\
GM0708 & B03 & 29.047 & 90.164 & 10 & 33.81 & 2195.8 & -1.35 & -47.4 & 9.1 \\
GM0708 & B06 & 28.993 & 90.076 & 18 & 36.00 & 2290.7 & -0.95 & -23.7 & 4.4 \\
GM0708 & B09 & 28.825 & 89.994 & 37 & 36.48 & 2259.7 & -0.30 & -17.3 & 41.9 \\
GM0708 & C04 & 28.951 & 90.525 & 10 & 32.10 & 2159.0 & -1.25 & -57.4 & 31.3 \\
GM0708 & C06 & 28.853 & 90.463 & 18 & 35.83 & 2241.7 & -0.38 & -19.7 & 5.3 \\
GM0708 & C08 & 28.789 & 90.277 & 18 & 35.91 & 2247.3 & -0.58 & -22.5 & 26.3 \\
GM0708 & D03 & 28.718 & 90.834 & 14 & 35.88 & 2260.2 & -0.69 & -21.6 & 8.1 \\
GC0907 & D2 & 28.584 & 91.024 & 21.6 & 35.70 & 2340.2 & -1.47 & -23.5 & 14.7 \\
GC0907 & D2 & 28.584 & 91.024 & 17.3 & 35.41 & 2320.3 & -1.23 & -22.1 & 49.2 \\
GC0907 & D1 & 28.785 & 91.008 & 9.3 & 34.04 & 2305.7 & -2.02 & -28.9 & 4.7 \\
\hline
\end{tabular}

